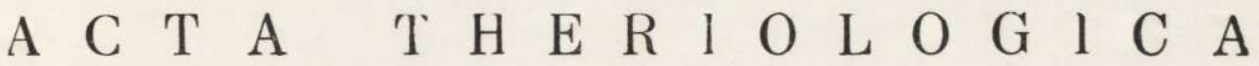

VOL. XVI, 19: 295-328.

BIAŁOWIEŻA

November, 1971

Wiera W A L K O W A

\section{The Eifect of Exploitation on the Productivity of Laboratory Mouse Populations ${ }^{1}$}

[With 5 Tables \& 17 Figs.]

The experiments covered 40 populations of confined house mice bred in wooden cages during 70 weeks. Part of the each population was removed on the same day at 12 week intervals. It was determined that an increase in the intensity of exploitation in the entire gradient applied (from $0 \%$ to $670 \%$ of the total number of individuals) leads to corresponding changes in some population parameters: (a) increase in the survival rate of mice not older than two weeks, and (b) decrease in the average numbers and biomass of the population, in the numerical peak, in body weight losses, and in survival rate in the age group 11-14 weeks. Some of the parameters varied only within certain limited ranges of exploitation intensity i.e. average number of newborn mice per one female, and number of adult females. On the other hand, the body weights and biomass production of the population displayed an even counteracting character of changes for various ranges of exploitation intensity.

Biomass production and the total number of individuals in the population were compensated only when the exploitation rate did not exceed $32-34 \%$ of the total number of individuals in the population. A further intensification of exploitation led to a decrease in the value of these parameters. The main compensating factor was the survival rate of mice not older than two weeks. Exploitation led to alterations in the percentage of various age groups in the biomass production of the population.

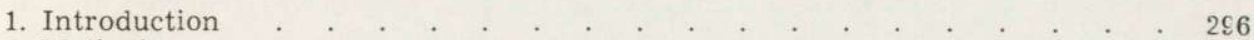

2. Methods . . 296

3. Dependence of selected population parameters on the intensity of exploitation

3.1 General characteristics of the dynamics of numbers $(N)$ and biomass $(B)$

3.2 Production of the population $(P)$.

3.3 Number of individuals $(v)$.

3.4 Survival of individuals $(S)$

3.5 The individual growth curve.

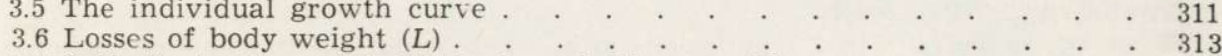

3.7 Self-elimination of individuals and biomass $(E) \cdot+\cdot \cdot 313$

1) The initial analysis of the materials included in this paper was presented at the meeting of the Working Group on Small Mammals (International Biological Programme) in Oxford in 1967. 
4. Discussion

5. Conclusions References Streszczenie

\section{INTRODUCTION}

In the last ten years, the problems of the dependence of the population production on the intensity of its exploitation, the changes sparked off by exploitation and the action of compensation mechanisms have acquired considerable practical significance.

Under laboratory conditions there has so far been investigated, first of all, the exploitation of algae population ( $\mathrm{K} \mathrm{e} \mathrm{t} \mathrm{c} \mathrm{h} \mathrm{u} \mathrm{m,} \mathrm{Lilli} \mathrm{ck} \mathrm{\&} \mathrm{R} \mathrm{e} \mathrm{d-}$ fi eld, 1949), and also of invertebrates: Lucylla ( $\mathrm{Nichols} \mathrm{o} \mathrm{n,} \mathrm{1954),}$ Daphnia (S l o b o d k i n, 1957, 1962), Tribolium (W a t t, 1958), Brachionus (Hillbricht-Ilkowska \& Pourriot, 1969).

The aim of the present study has been to investigate the effects of exploitation on confined mouse populations under laboratory conditions. The author has attempted to establish the dependence of production on exploitation, changes in the population being the result of variations in the intensity of exploitation, and also compensation mechanisms. The author supposes that such studies may contribute to a better understanding of the processes caused by the elimination of individuals from the vertebrate populations living at large.

\section{METHODS}

The study was carried out on 40 confined laboratory populations of white mice (Mus musculus Linnae us, 1758) during the period from July 1965 until November 1966 (70 weeks in all) under laboratory conditions. Each population was placed separately in wooden cages $(160 \times 40 \times 10 \mathrm{~cm}$ ) (Fig. 1). At the beginning, each of the 40 populations consisted of 6 females and 3 males about 3 months old.

The animals were given unlimited water and food (granulated mixture $M S L$ ), and twice a week they were supplied with sprouting wheat seeds and milk. Once every two weeks all the cages were cleaned, the old litter (sawdust) was removed and replaced with a clean supply, and all the mice were weighed.

The cages were checked every day, the number of newborn mice and their total weight were recorded (all the mice born on the same day were weighed together), and then these newborn mice were weighed successively twice a week, again together. Each individual was marked with a separate number painted on the hair in its 4-th or 5-th week of life, and from that moment until its death it was weighed separately every two weeks.

After 10 weeks (and in 7 populations after 34 weeks) from the moment when the experiment was initiated, the exploitation was begun, i.e. the removal of mice from the population.

There are at least two methods of exploiting a population. The first of these consists in the removal of such a number of individuals which forms a specified per cent of the total number of individuals in the population $(v)$, during the study per- 
iod. The other consists in removing such a number of individuals which forms a specified per cent of the standing crop $(N)$ of the population at the time when each check is being carried out.

The application of the first method of exploitation would require a current analysis of the data obtained which would undoubtedly entail much more labour. And consequently the other method was adopted and the exploitation was put into practice by removing a certain varying number of mice but which makes up a fixed,
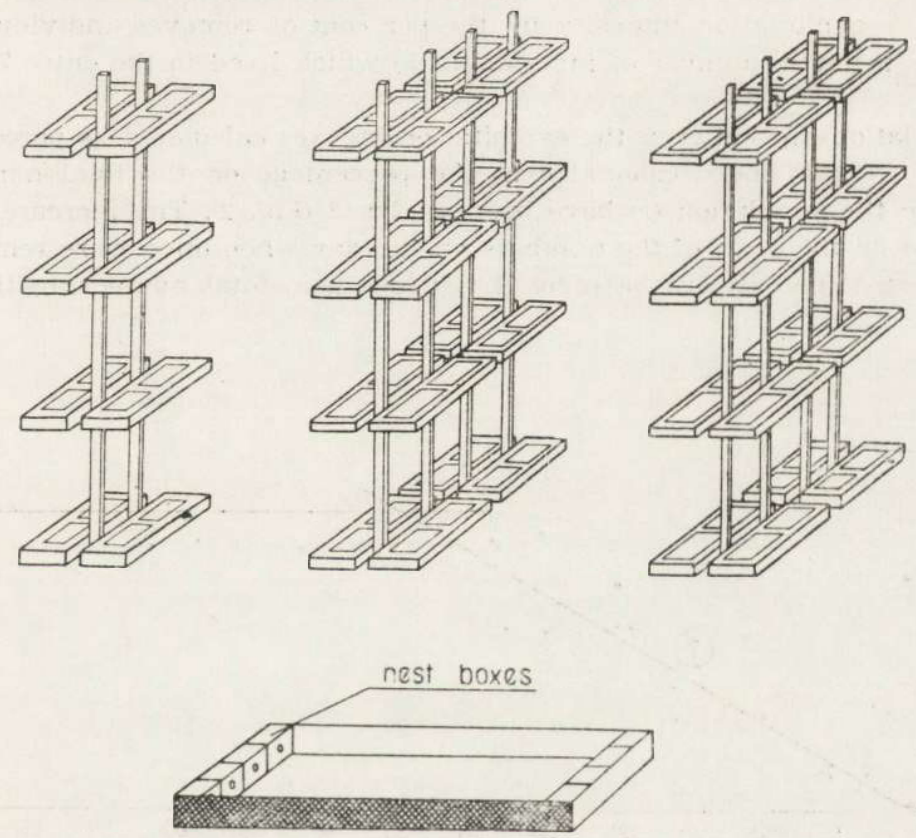

Fig. 1. Distribution of the cages with populations studied and the design of one of the cages.

Table 1

Pattern of the exploitation of the population (intensity of exploitation expressed as per cent of mice removed from the numbers of the population on the day of the removal).

\begin{tabular}{|l|rrrrrr|}
\hline Intensity of exploitation in $\%$ & 0 & 10 & 25 & 50 & 75 & 90 \\
\hline Number of populations & 6 & 6 & 5 & 5 & 5 & 13 \\
\hline
\end{tabular}

the same for each population, per cent of individuals found, on the given day, in the population (per cent of the standing crop). All the populations were divided into 6 groups according to the intensity of exploitation (Table 1). 
The removal of individuals from the population (exploitation) was carried out every 12 weeks, i.e. mice were removed five times during the study period in 33 populations and three times in seven populations.

All the populations were exploited proportionally to the numbers of age and sex groups.

As between the moments of exploitation varying numbers of individuals could have been born in different populations, and as their survival rate could vary, we might expect differing values of production for populations with similar numbers of individuals (standing crop) on the day were checked. And thus it is better to express the exploitation intensity by the per cent of removed individuals when the basis was the total number of individuals $(v)$ which lived in the entre 70 -week study period.

The relationship between the exploitation indexes calculated as percentage on the numbers $(N)$ and those calculated as the percentage on the total number of mice present in the population $(v)$ have been analysed (Fig. 2). The increase in the index calculated on the basis of the numbers on the day when mice were removed, corresponds to the increase in the index based on their total number in the population

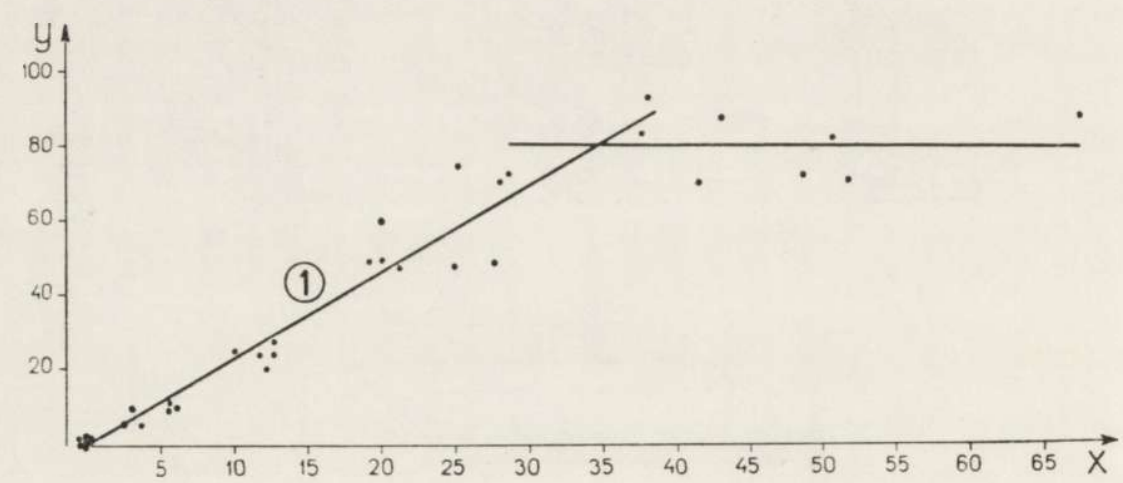

Fig. 2. Dependence of per cent of mice removed from the numbers on the day of the removal $(y)$ on per cent of mice removed from the total number of mice in the population $(x)$.

$$
\text { (1) } r=0.9863, \mathrm{n}=26, y^{\prime}=2.3990 x-1.3694
$$

until the moment when the latter reaches the value of $35 \%$. Any further increase in the value of the second index has no effect on the first index. Thus the index of exploitation calculated as a per cent of mice removed from the total number of individuals in the population has a wide range of variation as compared with the index presented in the form of a per cent of mice removed from the total numbers on each exploitation date, and consequently it seems to be better for the purpose of comparing with various population parameters.

Most of the data obtained were analyzed with the following statistical methods: (a) the existence of linear dependence was concluded from the value of correlation coefficient $(r)$ and the estimate of its significence $P=0.05$. (b) after determining the significance of the correlation coefficient, the dependences studied were calculated from the equation of linear regression: 


$$
y=a x+b
$$

Taking into account the possibility of being faced with a curvilinear dependence, the shape of which might be difficult to determine, the empirical data of the parameters studied were divided, for the sake of convenience, into classes of different values. However because, the variation of one parameter as a result of the increase in the other parameter is rather continuous and it is difficult to establish the limits of the classes, the values approaching these limits were included in both the neighbouring classes. For each of these classes the correlation coefficient was calculated, and in the case of its significance, also an equation of linear regression $\left.(y)^{2}\right)$. The data presented in Fig. 14 form an exception as the curvilinear dependence was calculated there from the following formula:

$$
y=a \cdot b^{x}
$$

The values of correlation coefficient and simple regression $y$ for the recorded significant linear dependences are presented in Table 2. In the case of significant

Table 2

Values of the correlation coefficients $(r)$ between the degree of exploitation and the remaining parameters studied and the respective for these dependences equation

\begin{tabular}{|c|c|c|c|c|}
\hline No. & Parameters studied & $r$ & $y=a x+b$ & $\begin{array}{l}\text { Number of } \\
\text { attemps }\end{array}$ \\
\hline 1 & $\begin{array}{l}N \text { on the day of the } \\
\text { checking } \\
B \text { on the day of the }\end{array}$ & -0.6510 & $-0.8270 x+80.1136$ & 40 \\
\hline & checking & -0.7630 & $-21.5286 x+1645.7260$ & 40 \\
\hline 3 & Numerical peak & -0.6447 & $-1.1189 x+110.2882$ & 40 \\
\hline 4 & $\begin{array}{l}\text { Period until the moment } \\
\text { when the numerical peak } \\
\text { occurred } \\
\text { Survival in the 2nd week }\end{array}$ & -0.34 & 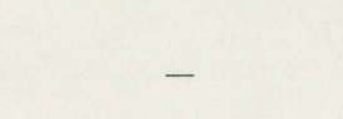 & 31 \\
\hline 6 & $\begin{array}{l}\text { of life } \\
\text { Age at which males and } \\
\text { females have the same }\end{array}$ & 0.6525 & $0.3912 x+62.2736$ & 40 \\
\hline 7 & body weight & -0.5394 & $-0.0589 x+10.9787$ & 40 \\
\hline$\gamma$ & & -0.9188 & $-0.8143 x+90.2847$ & 40 \\
\hline
\end{tabular}
of regression $(y)$.

curvilinear dependences, the empirical data of the factors studied and of simple regression are presented graphically - giving also the values of $r$ and $y$.

In the cases when no significant linear dependence between the factor studied and the degree of exploitation intensity was recorded, the author calculated the mean value of the factor and the confidence interval of this value ( $\mathrm{F}$ is z, 1958).

2) As a limit of two successive classes the author has taken the point of intersection of (1) the respective lines of regression when $r$ was significant for the two classes, or (2) the intersection of the line of regression with the arithmetical mean of the class in which $r$ was not significant. And thus some values of points where the curve changed its course may slightly differ from those presented at the Conference in Oxford where they were estimated on the basis of the intersection of the lines of regression calculated irrespective of the significance of $r$. 


\section{DEPENDENCE OF SELECTED POPULATION PARAMETERS ON THE INTENSITY OF EXPLOITATION}

\subsection{General Characteristics of the Dynamics of Numbers $(N)$ and of the Biomass $(B)$}

The number of individuals in mouse populations varies considerably both in free-living populations (Strecker, 1954; S out hwick, 1958; Petrusewicz \& Andrzejewski, 1962; Adamczyk \& Pe$\mathrm{t} \mathrm{ru} \mathrm{s}$ e w i c z, 1966, and others) and in those which are confined (B r o w n, 1953; Strecker \& Emlen, 1953; Southwick, 1955a; Crowcroft \& R ow e, 1957; Petrusewicz, 1957, 1960, 1963; Walk ow a \& Petrusewicz, 1967). The periods of time between numerical extremes differ considerably.

In order to be able to determine whether exploitation affects the numerical level of the population, the dependence of the average number of individuals $(N)$ according to the degree of exploitation intensity was analysed (Table 2 , line 1 ). It has been concluded that the average numbers decrease when exploitation becomes more intensive. When no exploitation is applied, the average numbers of the population amount to 80.1 individuals, and when the exploitation index reaches $67.4 \%$ it falls down to 24.4 individuals.

An analysis of the average biomass $(B)$ per one checking and per one population as dependent on the degree of exploitation intensity was carried out (Table 2 , line 2 ). The calculated linear regression served to estimate the value of biomass at extreme degrees of exploitation intensity. It turned out that the average level of biomass decreases when exploitation is intensified. When there is no exploitation it amounted to 1,646 grammes and it fell down to 195 grammes when exploitation is most intensive.

The peak population size also depends on the degree of exploitation intensity (Table 2, line 3). After removing $67.4 \%$ of individuals from the population, the peak population size amounts only to 34.9 individuals, while in the case when no exploitation is applied it reaches 110.3 individuals.

No dependence was recorded betwen the degree of exploitation intensity and the length of time between the initiation of the experiment and peak population size (Table 2). The peak could be recorded, on the average, $27.6 \pm 2.0$ weeks after the day when the population had been established.

\subsection{Production of the Population $(P)$}

Production $(P)$ was calculated as a sum of all the gains in body weight of each individual together with body weights of all the newborn mice minus the sum of all the losses in body weight of separate mice ( $\mathrm{P} \mathrm{e} \mathrm{tr} \mathrm{u-}$ 
s ew ic z, 1966, 1967). It has already been found ouf (W a l k ow a \& Petrusewicz, 1967) that the total gain in the population biomass can vary significantly although the populations are started with the same initial numbers of individuals and are kept under indentical conditions. The total production can also vary (Table 3 ) even when the same degree of exploitation intensity is applied. For instance, population No 39 produced twice as much of biomass as population No 1 .

Nonetheless it was determined that the production increases only when exploitation rises to $31.6 \%$ (from $721 \mathrm{gm} / 12$ weeks to $1,152 \mathrm{gm} / 12$ weeks).

Table 3

Production of a mouse population $(P)$ in the period of 70 weeks recalculated per one year.

\begin{tabular}{|c|c|c|c|c|c|}
\hline $\begin{array}{c}\text { Population } \\
\text { No. }\end{array}$ & $\begin{array}{l}\text { Per cent of } \\
\text { exploitation }\end{array}$ & $\begin{array}{c}P \\
\text { (in } g \text { ) }\end{array}$ & $\begin{array}{c}\text { Population } \\
\text { No. }\end{array}$ & $\begin{array}{l}\text { Per cent of } \\
\text { exploitation }\end{array}$ & $\begin{array}{c}P \\
\text { (in g) }\end{array}$ \\
\hline 1 & 0.0 & 2360 & 22 & 19.8 & 4056 \\
\hline 14 & 0.0 & 3559 & 23 & 20.9 & 5630 \\
\hline 18 & 0.0 & 2652 & 27 & 21.1 & 4670 \\
\hline 20 & 0.0 & 3968 & 15 & 22.9 & 2660 \\
\hline 28 & 0.0 & 3656 & 6 & 24.3 & 4558 \\
\hline 39 & 0.0 & 4801 & 37 & 25.4 & 3294 \\
\hline 32 & 2.7 & 3289 & 24 & 27.6 & 4299 \\
\hline 4 & 3.1 & 3822 & 13 & 27.9 & 3749 \\
\hline 34 & 3.6 & 2765 & 36 & 28.5 & 5102 \\
\hline 9 & 5.3 & 2656 & 35 & 32.1 & 6143 \\
\hline 8 & 5.5 & 3194 & 40 & 36.0 & 7083 \\
\hline 19 & 6.0 & 3196 & 38 & 37.3 & 3993 \\
\hline 7 & 10.6 & 3839 & 10 & 37.8 & 2946 \\
\hline 5 & 11.6 & 3335 & 31 & 41.5 & 3179 \\
\hline 11 & 11.9 & 3100 & 2 & 42.9 & 4246 \\
\hline 17 & 12.3 & 2628 & 26 & 48.7 & 4680 \\
\hline 29 & 12.7 & 6156 & 25 & 50.7 & 2781 \\
\hline 12 & 14.5 & 2637 & 33 & 51.5 & 2714 \\
\hline 16 & 18.7 & 3974 & 30 & 59.9 & 2163 \\
\hline 3 & 18.9 & 4667 & 21 & 67.4 & 2049 \\
\hline
\end{tabular}

A further increase in the exploitation rate results in a decrease in the production value. When $67.4 \%$ of individuals are removed production amounts to only $395 \mathrm{gm} / 12$ weeks (Fig. 3).

The character of the changes in the size or population production depends also on the exploitation rate (Fig. 4). When no exploitation is applied production increases sharply in the initial period quickly reaching its highest peak and its lowest level of decline. When the exploitation range varies from $2.7-15 \%$ the curve of production is similar, however its peak is lower and the decline less pronounced. The value of production when exploitation varies from $15-30 \%$ is quite steady. When the exploitation is intensified still further, production declines after a relatively low peak, 


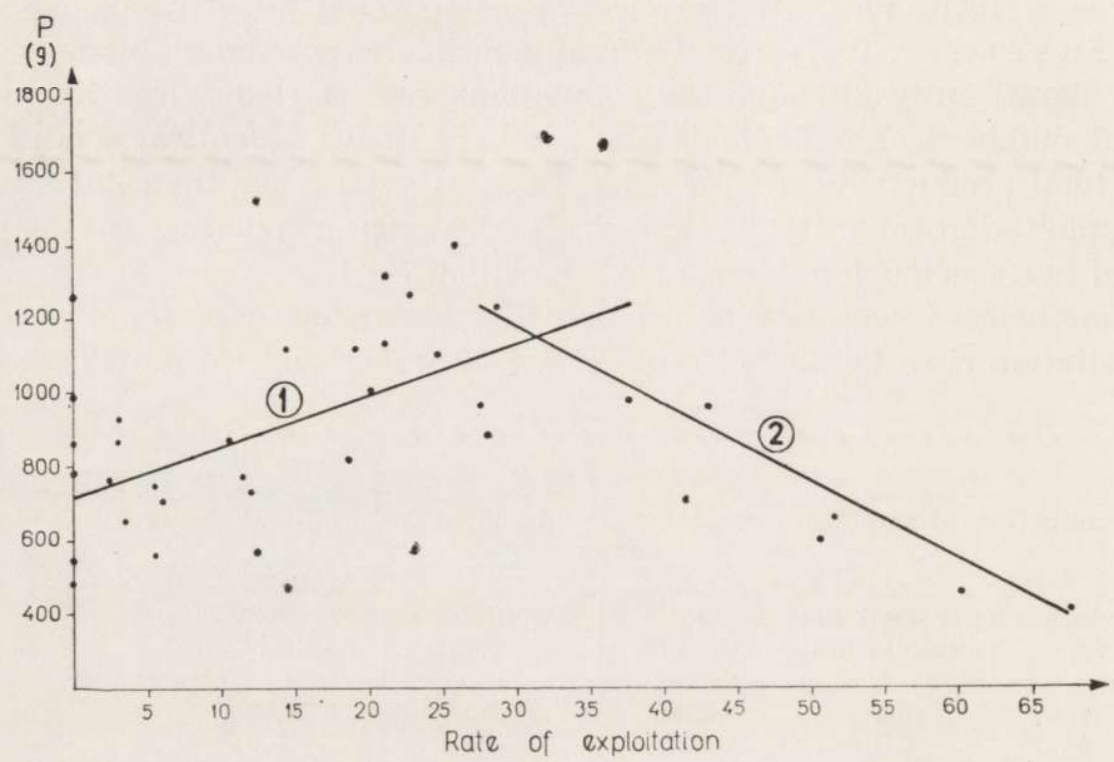

Fig. 3. Dependence of the biomass production $(P)$ on the degree of exploitation. $P$-recalculated as an average value for the period of 12 weeks when exploitation was applied (from the 10th until the 70th week of the study period).

(1) $r=0.4881, \mathrm{n}=32, y^{\prime}=13.6208 x+720.7243$

(2) $r=-0.6492, \mathrm{n}=14, y^{\prime}=-21.1450 x+1820.3988$

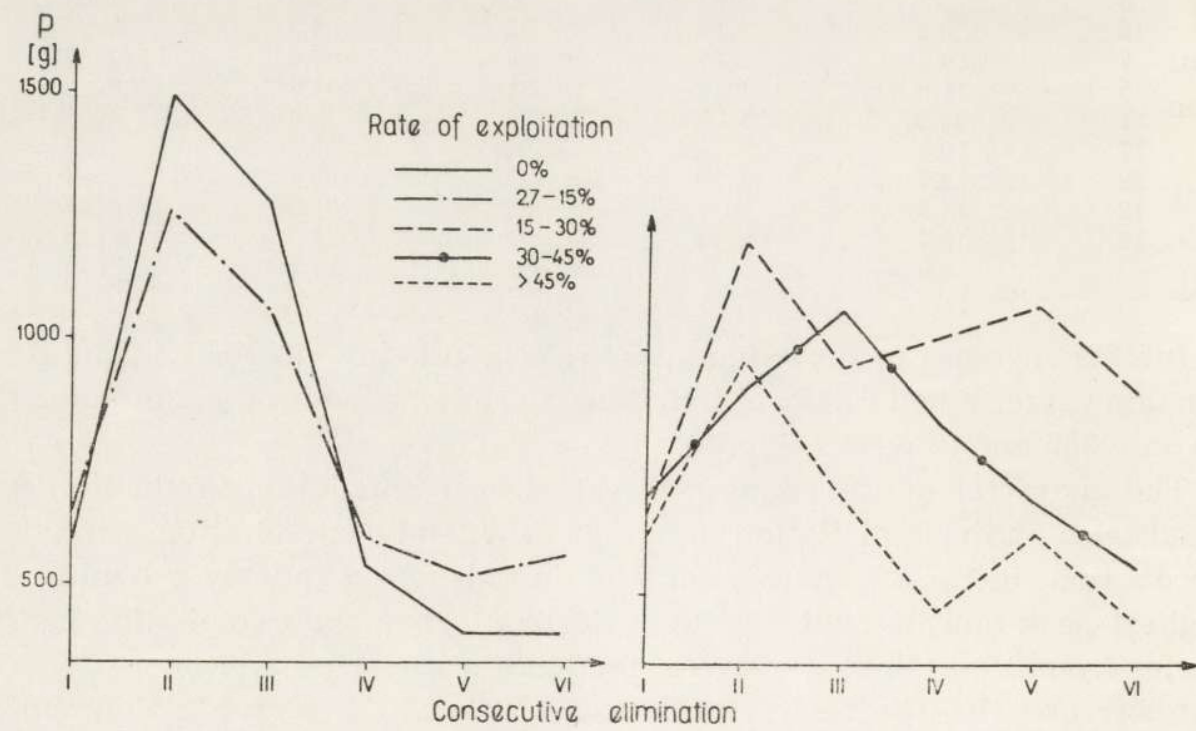

Fig. 4. Production of the population in the successive periods while the experiment was carried out ( $P$ for 12 weeks). 
but its course does not reveal such a wide gap between the peak and decline of production as for a small scale of exploitation.

In cach population the production of young individuals (up to 5 weeks) was distinguished from the production of older mice (separately males and females). The percentages of males, females, and various age groups of young mice produced in the populations were calculated (Fig. 5).

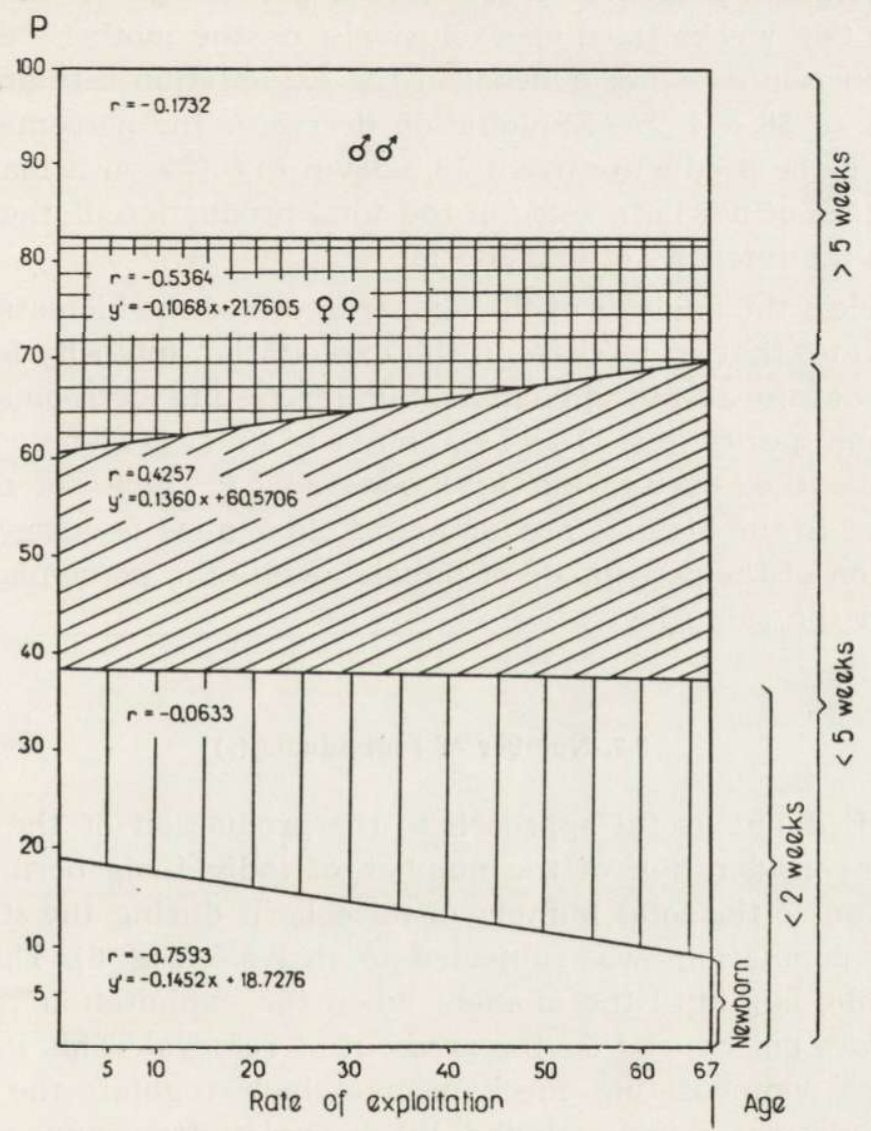

Fig. 5. Percentage of different age classes of individuals produced in the population according to the degree of exploitation.

These percentages of separate age and sex groups do not always depend on the intensity of exploitation. The percentage of males produced does not depend on the degree of exploitation intensity and it amounts, on average, to $16.8 \pm 1.0 \%$ of the total biomass production of the population. On the other hand the percentage of females produced decreases when the exploitation is intensified from $21 \%$ down to $14.6 \%$. The percentage of young mice (not older than 5 weeks) is high and amounts to $60.6-69.7 \%$.

Acta theriol. 20 
The high percentage of juveniles in the production of biomass is known for populations of small rodents which were not artificially exploited (Walkowa \& Petrusewicz, 1967; Petrusewicz \& Walkowa, 1968; Petrusewicz, Andrzejewski, Bujalska \& Gliw i c z, 1968). The introduction of exploitation increases the percentage of young individuals produced. However the percentage of individuals not older than two weeks (feeding exclusively on the mother's milk) in the entire production does not depend on the exploitation rate and amounts, on average, to $38 \pm 1.2 \%$. Exploitation decreases the percentage of newborn mice in the production from 18.7 down to $8.4 \%$, so it may be stated that the share of newborn mice in the total production of the population depends on the intensity of exploitation.

Nevertheless the analysis of the age structure of the biomass being produced indicates that an increase in the exploitation intensity leads to "rejuvenation " of the resulting biomass. Similar results were obtained in the case of other species (e.g. Davis, Christian \& Brons on, 1964, for the marmot; Golodushko \& Fomenkov, 1969, for the beaver). The increase in the biomass production of older mice is achieved through the reduction of the percentage of females while the percentage of males remains on the same level.

\subsection{Number of Individuals ( $v$ )}

A simplified but useful approach to the production of the population can be the consideration of the number of individuals born in the population. And so the total number of mice born during the study period in separate populations was subjected to analysis (Fig. 6). This figure is very variable, but until the moment when the exploitation rate reaches $34.2 \%$, it does not depend on the gradient of removal. This indicates the existence of compensating mechanisms which regulate the number of mice in populations being exploited. When exploitation range was extended from $0 \%$ to $34 \%$ over the period of 70 weeks, $731.6 \pm 63.0$ individuals on average, were born in each population. Any further increase in the exploitation rate leads to a decline in the number of newborn mice (per population) down to 210.5 .

The number of newborn mice in a population depends on (1) the average number of newborn per female, and (2) the number of breeding females. To be able to estimate these two indexes, we must have, data on the age at which the females have their first litter. Murray (after Grünbe $r g, 1952$ ) recorded here wide variations as the age of females ranged from 55 to 405 days. 


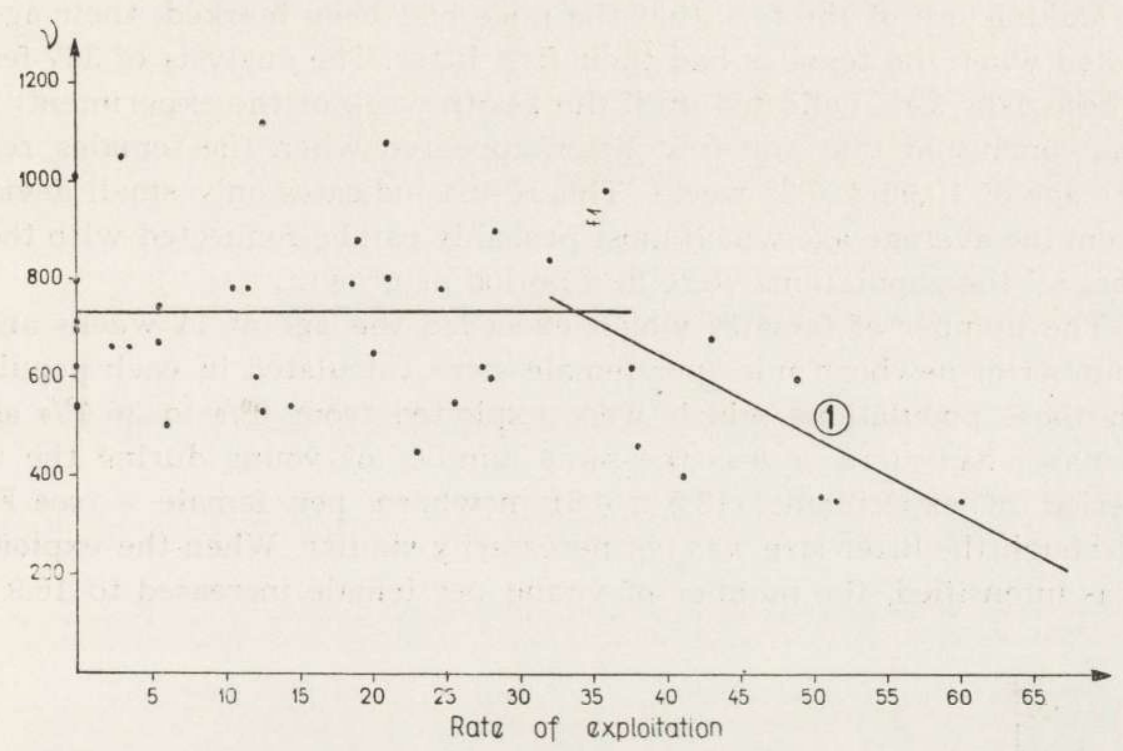

Fig. 6. Dependence of the number of newborn mice per cage $\left(v_{r}\right)$ on exploitation. (1) $r=-0.7517, \mathrm{n}=11, y^{\prime}=-15.7283 x+1270.6372$

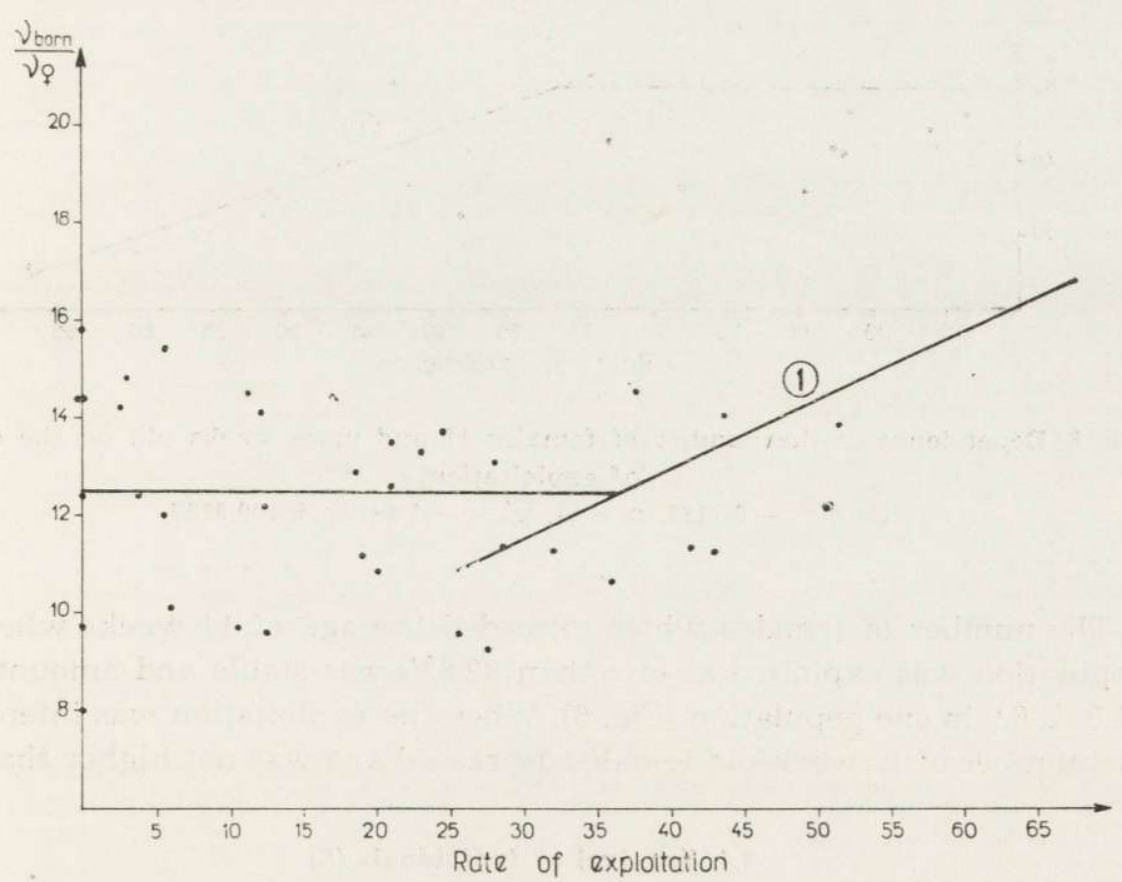

Fig. 7. Dependence of the number of newborn mice per female 11 and more weeks old on the exploitation intensity.

(1) $r=0.5616, \mathrm{n}=15, y^{\prime}=0.1445 x+7.1941$ 
Making use of the fact that the mice had been marked, their age was noted when the females had their first litter. The analysis of 367 females (these data were collected until the 24.5th week of the experiment) led to the conclusion that the first litter appeared when the females reached the age of $10.96 \pm 0.25$ weeks. This result indicates only small deviations from the average age which most probably can be connected with the fact that all the populations were in a period of growth.

The number of females which exceeded the age of 11 weeks and the number of newborn mice per female were calculated in each population. In those populations which were exploited from $0 \%$ to $36.4 \%$ all the females had more or less the same number of young during the whole period of experiment $(12.5 \pm 0.81$ newborn per female - see Fig. 7$)$ although the litter size was not necessarily similar. When the exploitation was intensified, the number of young per female increased to 16.9.

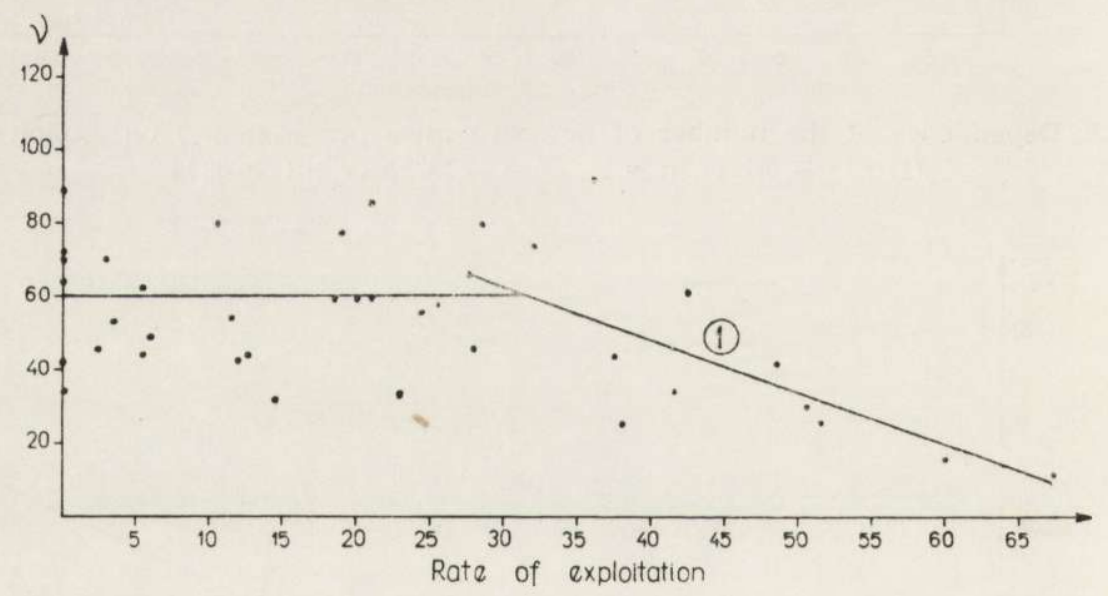

Fig. 8. Dependence of the number of females 11 and more weeks old on the degree of exploitation.

(1) $r=-0.7422, \mathrm{n}=14, y^{\prime}=-1.4970 x+109.8287$

The number of females which exceeded the age of 11 weeks when the population was exploited at less than $32.6 \%$ was stable and amounted to $61.0 \pm 6.9$ in one population (Fig. 8). When the exploitation was intensified the number of 11 week-old females decreased and was not higher than 8.9.

\subsection{Survival of Individuals (S)}

In the populations exploited the survival of individuals was calculated for each period of life according to the following formula: 


$$
S=\frac{\nu_{t}}{\nu_{t-1}-\nu^{\prime}} \cdot 100
$$

where $\nu_{t}$ - number of mice at the age of $t$,

$v_{t-1}$ - number of mice at the age from which one unit of time is reduced $(t-1)$,

$v^{\prime}$ - number of mice removed at an agebetween $t-1$ and $t$.

The data obtained with help of above formula (percentage of individuals surriving a particuliar, successive week of their life) were used as a basis

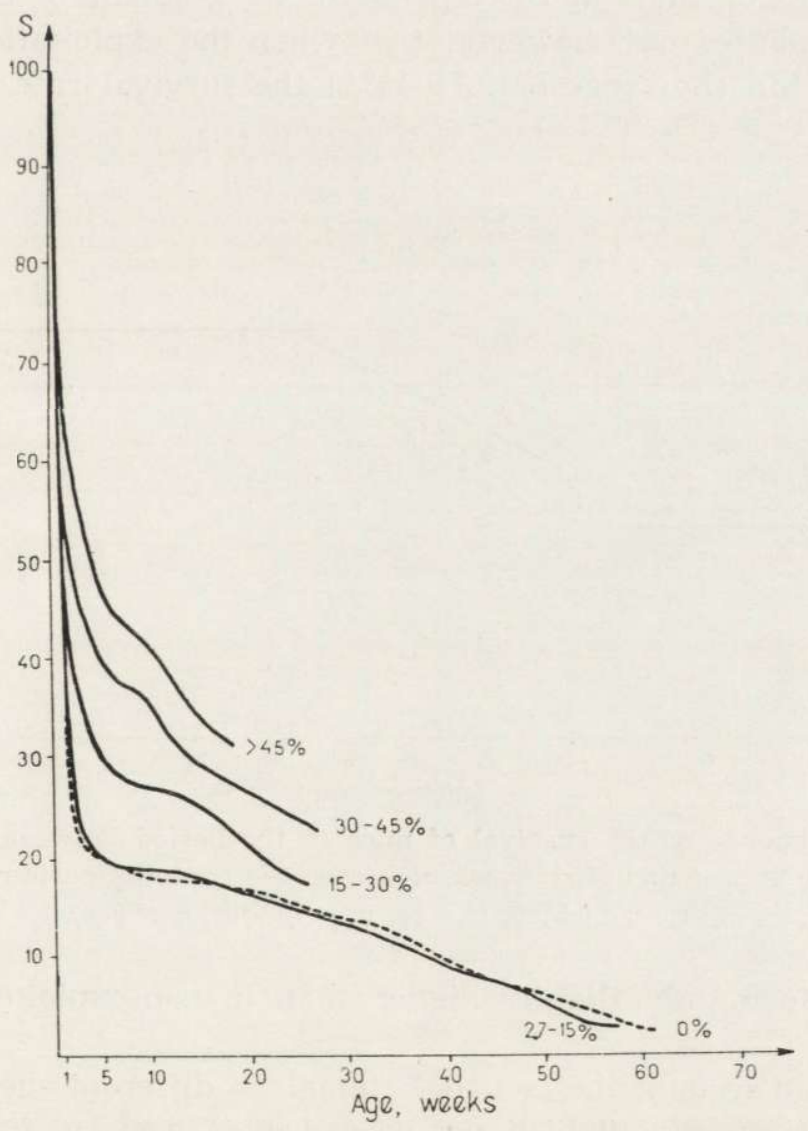

Fig. 9. Survival of mice in relation to the exploitation intensity.

to calculate the percentage of individuals surviving for the entire period of their life within the experimental population, beginning with their birth (Fig. 9). 
In the unexploited populations the same index could be achieved by calculating directly the per cent of individuals which survived until the given age $\left(v_{t}\right)$ from the total number of mice born $\left(v_{r}\right)$ :

$$
S=\frac{\nu_{t}}{\nu_{r}} \cdot 100
$$

In all the populations studied the lowest survival rate was recorded in the 1st and 2nd weeks of life. Similar results for confined populations were obtained by S outhwick (1955), Petrusewicz (1960), Wa lkow a \& Petrusewicz (1967), and others.

The curves of survival correspond to the gradient of exploitation. It should be pointed out, however, that when the exploitation is least intensive (within the range of $2.7-15^{\circ} \%$ ) the survival rate until the 16 th

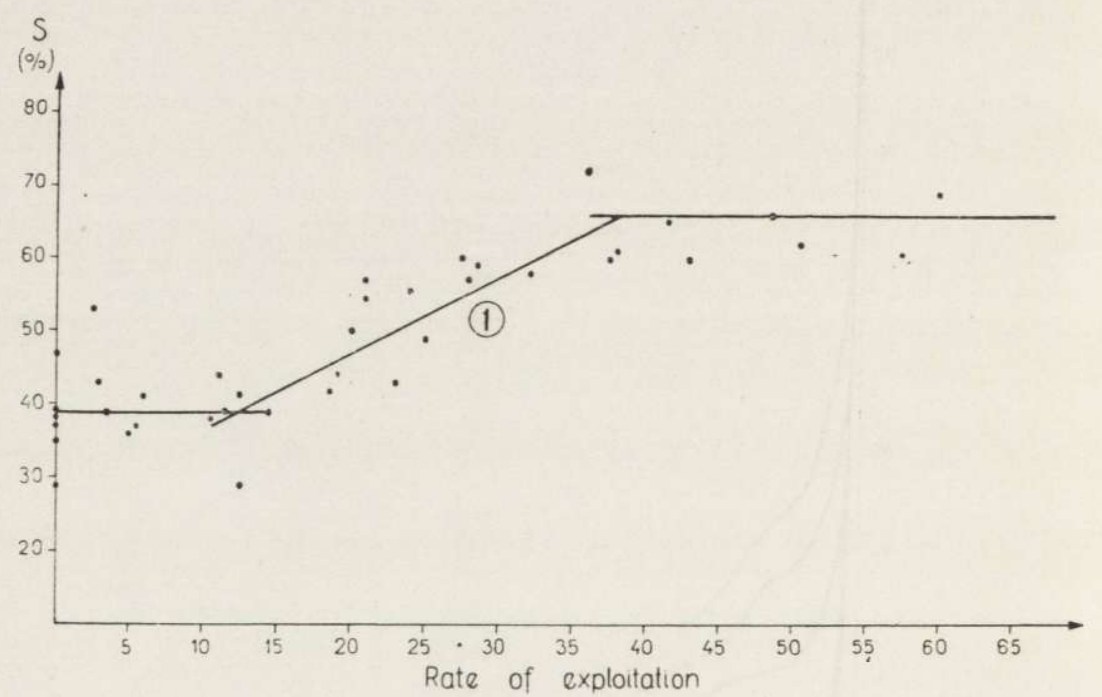

Fig. 10. Dependence of the survival of mice in the period between their birth and the end of their first week of life on the exploitation intensity.

$$
\text { (1) } r=0.8789, \mathrm{n}=21, y^{\prime}=1.0650 x+25.9362
$$

week of life is only slightly higher than in non-exploited populations (Fig. 9).

Taking into account the fact that animals of different age can react differently to a stimulus (which was proved by Varley \& Gradwell, 1962 , in respect to the density of Operophtera brumata L.) the following items were calculated for separate age groups:

1. per cent of mice surviving a given week from the number of mice which survived until the previous week (in the case of exploited populations formula (1) was used), 
2. coefficient of correlation between the survival rate calculated and the degree of exploitation intensity.

The analysis of the survival rate of mice in their first week of life indicated that this parameter increases together with the intensification of exploitation when the latter is in the range of $12.3-37.7 \%$ (Fig. 10). The exploitation outside this range has no effect on the survival rate. For the exploitation intensity up to $12.3 \%$ it amounts, on average, to $39.0 \pm$ $2.6 \%$, while over $37.7 \%$ it amounts, on average to $66.1 \pm 3.7 \%$.

Some dependence of the survival rate on the degree of exploitation intensity was recorded for the second week of the life of mice (Table 2, line 5). When no exploitation is applied the survival rate amounts then to $62.3 \%$ (on average), and when exploitation reaches $67.4 \%$ the survival rate increases up to $88.6 \%$.

\section{Table 4}

Values of the coefficient of correlation $(r)$ between the degree of exploitation and the survival of mice in separate age groups. Values which are significant at $P=0.05$ are set in boldface.

\begin{tabular}{|c|c|c|c|c|c|c|c|c|c|}
\hline Age (weeks) & $1-2$ & $3-4$ & $5-6$ & $7-8$ & $9-10$ & $11-12$ & $13-14$ & $15-16$ & $17-18$ \\
\hline $\begin{array}{l}\quad r \\
\text { Avg. } S \\
\text { conf. interv }\end{array}$ & $\begin{array}{l}0.94 \\
\text { val }\end{array}$ & $\begin{array}{r}0.03 \\
84.4 \\
\pm 1.5\end{array}$ & $\begin{array}{r}-0.11 \\
90.7 \\
\pm 1.8\end{array}$ & $\begin{array}{r}-0.08 \\
98.1 \\
\pm 0.6\end{array}$ & $\begin{array}{r}-0.20 \\
97.5 \\
\pm 0.7\end{array}$ & -0.72 & -0.76 & $\begin{array}{r}-0.28 \\
96.1 \\
\pm 1.3\end{array}$ & $\begin{array}{r}-0.22 \\
95.5 \\
\pm 1.4\end{array}$ \\
\hline
\end{tabular}

The survival rate of animals older than 2 weeks is low and no effect of the intensity of exploitation on their survival in separate two-week age periods was recorded. Average values of survival for separate age groups are presented in Table 4 . The only exception is the survival of $11-14$ week-old mice for which the effect of exploitation on the survival rate was recorded, i.e. survival decreases slightly when the exploitation is intensified (Fig. 11). The survival of $13-14-$ week-old females (per two-week unit) decreases when the exploitation is intensified: when no exploitation is applied it amounts to $97.3 \%$, and when the exploitation is at its highest it drops to $90.2 \%$. The survival of $11-12$ - week-old females and 11-14 - week-old males (also per two-week units) declines (from $97.3 \%$ to $86.8 \%$ ) only in the case of exploitation higher than $17.1 \%$. In the exploitation range between $0 \%$ and $17.1 \%$ the survival rate does not reveal any dependence on the exploitation intensity.

All the data on survival analysed above are concerned with the entire study period. In various periods of the life of the population the survival rate could vary depending on the phase of the population, density, etc. 
The survival rate of mice not older than two weeks was estimated in all the populations in the initial ten weeks of their growth when no exploitation was applied and when the numbers of all the populations were on the increase. The survival rate of mice up to two weeks old in these developing populations amounted to $69.6 \pm 5.5 \%$.

The survival of the same age group for the entire study period increased from $21.1 \%$ in the non-exploited populations to $66.4 \%$ in the most intensively exploited populations (Fig. 12). And thus only when the exploitation is very intensive the survival approximates that which can be recorded for populations in the phase of the initial numerical increase (density is then still low).

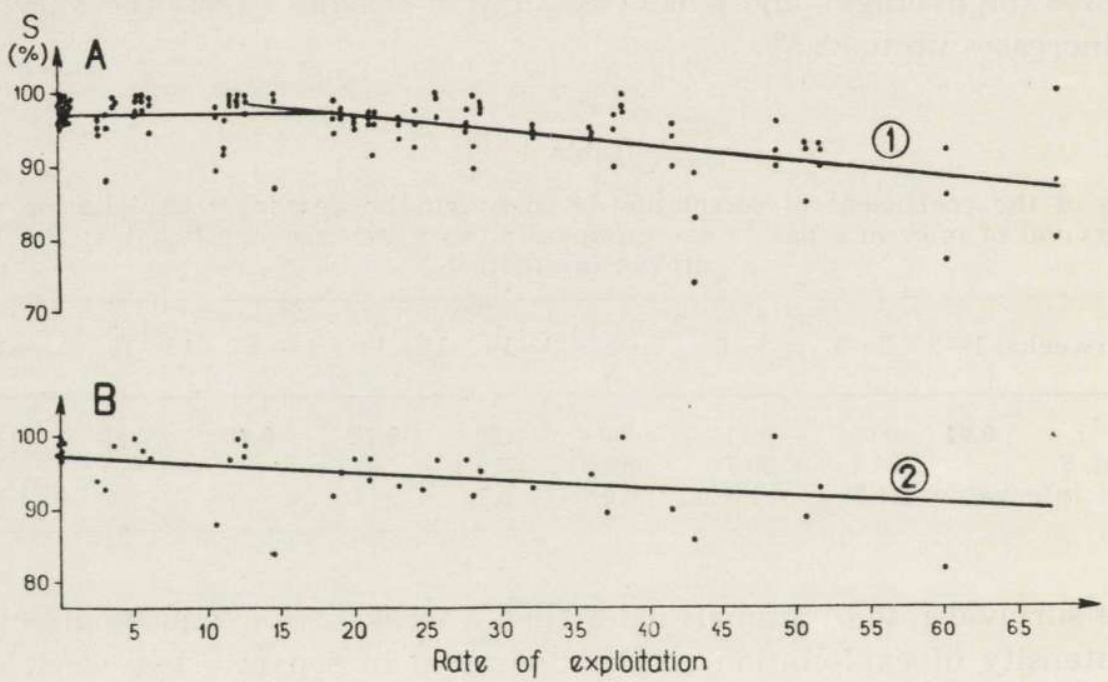

Fig. 11. Survival of 11-14 week old males and females in respect of exploitation. A) females in age $11-12$ weks; males in age 11-14 weeks

(1) $r=-0.6076, \mathrm{n}=78, y^{\prime}=-0.2182 x+101.5431$

B) females in age 13-14 weeks.

(2) $r=-0.4091, \mathrm{n}=40, y^{\prime}=-0.1050 x+97.2517$

In the course of exploitation both young and adult individuals were removed from the population. It has been attempted to estimate the effect of removing only juvenile individuals or only adult ones on the survival rate of the rest the population. To achieve this a further experiment was carried out.

Nine mouse populations, established with this purpose in mind, were divided into three groups according to the intensity with which the newborn mice removed $(0,50$ and $90 \%)$. In such cases the survival rate of individuals not older than two weeks has a gradient not corresponding to 
the degree of their exploitation (Table 5). In the non-exploited populations the survival was somewhat lower but this difference is not statistically significant when compared with the populations in which $50 \%$ of newborn mice and also with those in which as many as $90 \%$ were taken away.

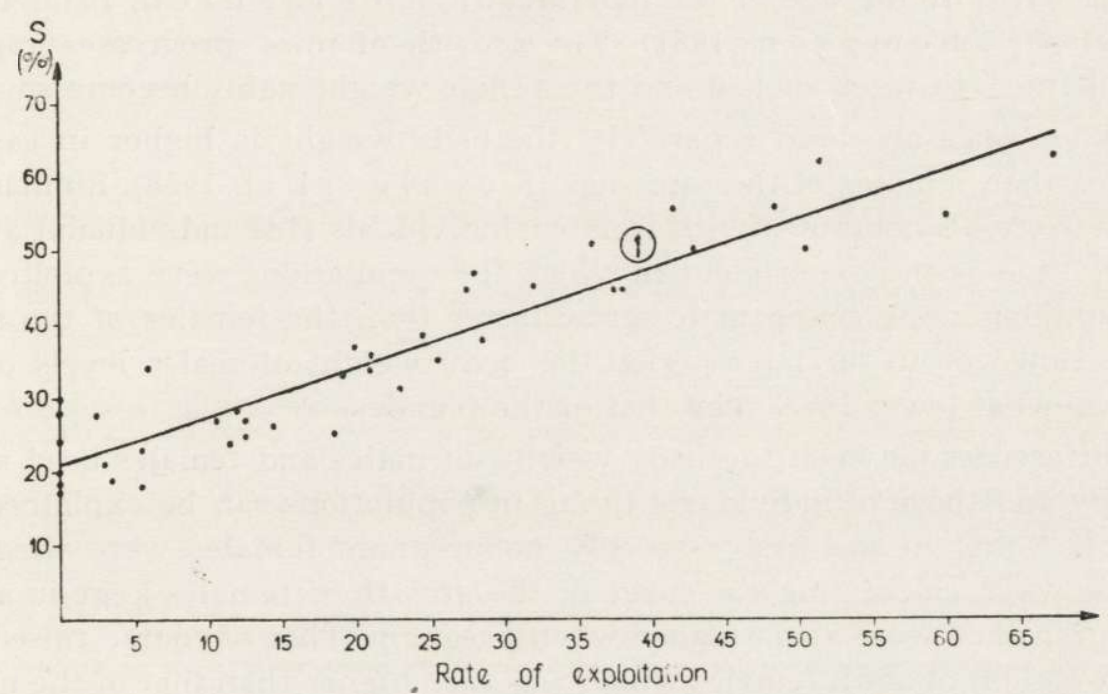

Fig. 12. Survival of mice in the period between their birth and the second week of their life in relation to exploitation.

$$
y^{\prime}=2850.0 \cdot 0.963 x, \mathrm{n}=40
$$

Table 5

Survival of mice up to two weeks of age and the exploitation of newborn mice.

\begin{tabular}{|c|c|c|c|c|c|}
\hline $\begin{array}{c}\text { Exploita- } \\
\text { tion of } \\
\text { newborn } \\
\text { mice }\end{array}$ & $\begin{array}{c}\text { Total } \\
\text { number of } \\
\text { newborn } \\
\text { mice }\end{array}$ & $\begin{array}{c}\text { Number of } \\
\text { mice which } \\
\text { survived } \\
\text { until the end } \\
\text { of the } \\
\text { 2nd week }\end{array}$ & $\begin{array}{c}\text { Per cent of } \\
\text { survival } \\
\text { until } \\
\text { the end } \\
\text { of the } \\
\text { 2nd week }\end{array}$ & $\begin{array}{c}\text { Population } \\
\text { number }\end{array}$ & $\begin{array}{c}\text { Period } \\
\text { when the } \\
\text { experiment } \\
\text { lasted } \\
\text { (in weeks) }\end{array}$ \\
\hline $0 \%$ & 290 & 201 & 69 & 3 & 15 \\
$50 \%$ & 152 & 117 & 77 & 3 & 15 \\
$90 \%$ & 45 & 33 & 73 & 3 & 24 \\
\hline
\end{tabular}

Thus it can be supposed that the survival rate of young individuals depends on the degree of exploitation of the adult individuals.

\subsection{The Individual Growth Curve}

The individual growth curve for separated breeding pairs of house mice is given in many papers ( $\mathrm{Br}$ od y, 1945; G r ü n be r g, 1952; K ov a l e vskij, 1958; Myrcha \& Walkowa, 1968) and also for mice living in 
populations (W a lkowa \& Petrusewicz, 1967). Some authors are of the opinion that the curve of individual growth can not be expressed with the help of a simple mathematical formula (M a y n a rd \& L o o s li, 1967), while the others attempt to find the dependence between the phase of growth and the age of the individual ( $\mathrm{S} \mathrm{h} \mathrm{malh} \mathrm{a} \mathrm{u} \mathrm{z} \mathrm{e}, 1935 ; \mathrm{Bro-}$ dy 1945; Thompson, 1961). The growth of mice progresses rapidly until the 12th week of life and then their weight gains become smaller.

When mice are bred separately, the body weight is higher in case of males than females of the same age (K ov a l evsk i j, 1958). Similar results were also obtained with isolated individuals (181 individuals) at the same time as the experiment in which the populations were exploited. In populations very young males grow faster than the females of the same age. However in the later period the body weight of males levels off at a somewhat lower level than that of the females.

Differences between the body weights of males and females bred separately and those of individuals living in populations can be explained by the fact that in the first case only nonpregnant females were weighed, while when calculating the curve of the growth of females kept in a population they were also weighed when pregnant. That of course raised the body weight of adult females which was then higher than that of the males of the same age.

An increase in the exploitation rate causes the shortening of the period when males are heavier than the females (Table 2, line 6). When no exploitation is applied males weight more or less the same as the females when they are at the age of 11 weeks while when the highest degree of exploitation intensity is applied the body weights are leveled off at the age of 7 weeks. This data may serve as a basis for the conclusion that an increase in exploitation quickens the development of the individual.

It can be added that the average body weight of mice of the same age varies quite considerably in different populations.

In order to establish whether exploitation affects the body weight of mice the populations were divided into 5 groups according to the gradient of exploitation: (1) with no exploitation, (2) exploitation up to $15 \%$, (3) exploitation between 15 and $30 \%$, (4) exploitation between 30 and $45 \%$, and (5) exploitation between 45 and $67 \%$. The average body weights of males and females from separate age groups of all the populations were calculated for each of these groups above. The average body weight was calculated jointly for males and females not older than 5 weeks because in that period the entire litter was weighed together.

No dependence between the body weight and the intensity of exploitation was recorded for individuals of the age up to 5 weeks. But for older 
ncividuals different curves of individual growth were arrived at for groups in which the intensity of exploitation varied (Fig. 13). Low exploitation (up to $15 \%$ but higher than $0 \%$ ) retarded the growth of males and fenales. The curve of the growth of both females and males is lower and the rate of its ascent is slower than in the non-exploited populations. In the case of exploitation more intensive than $15 \%$, any further increase of

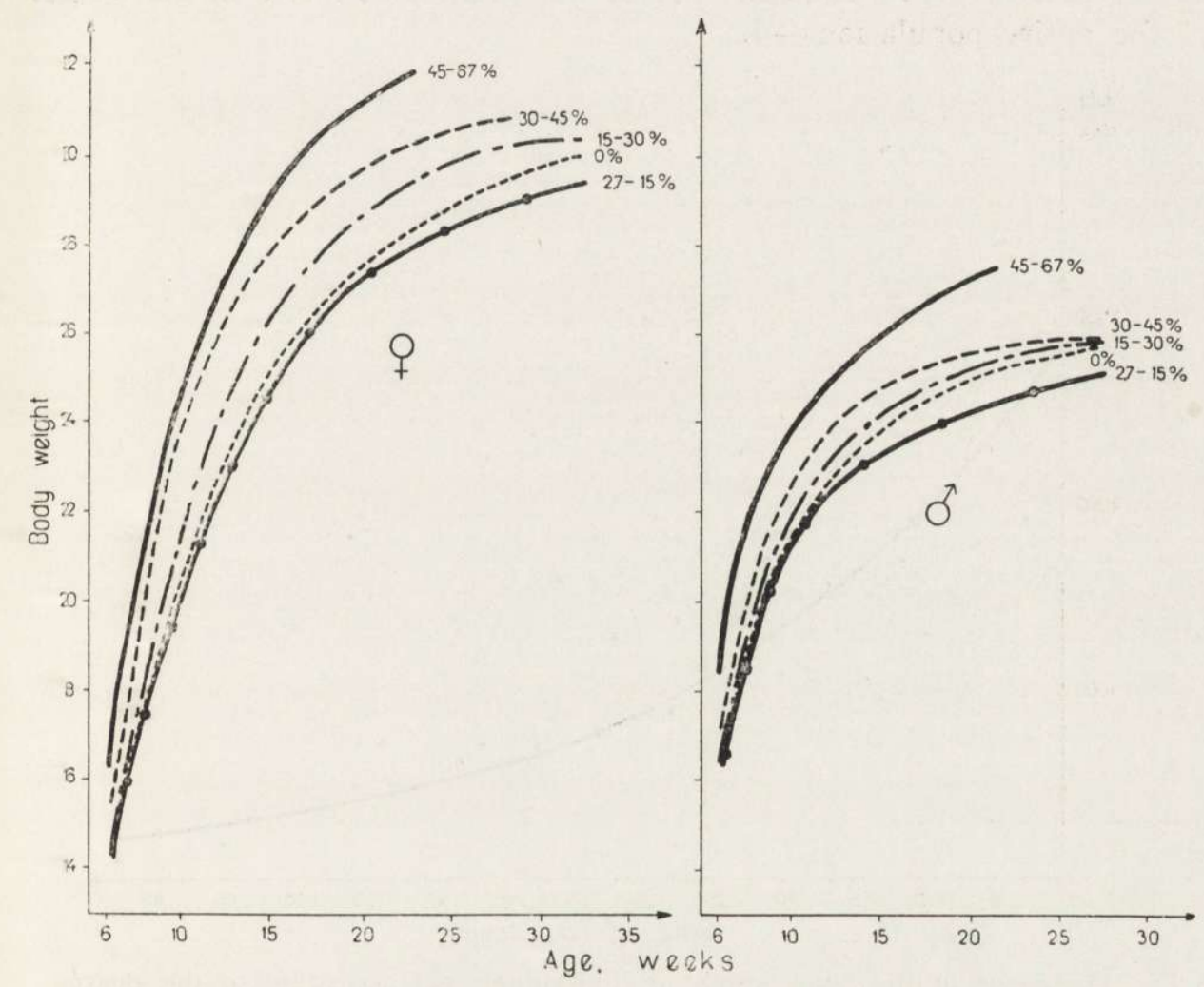

Fig. 13. The curve of individual growth for varying degrees of exploitation.

exploitation results in higher body weights of mice as compared with the mice of the same age living in non-exploited populations. The rate of growth and the curve of the growth of males and females rise according to the gradient of exploitation.

\subsection{Losses of Body Weight in Mice $(L)$}

Mice not only gain weight but they can also lose weight, even when they are supplied with unlimited food (W a l k ow a \& Petruse wi c z, 1967). Part of the body tissue is used, under certain conditions, to sustain 
the life of the individual, and losses of body weight can indicate the unfavourable situation in which the population finds itself. This means that the application of exploitation can also have some effect on losses of body weight.

A loss in body weight of an individual was defined as a loss in weight between two successive weighings. The sum of losses in body weight of all the individuals in the study period was defined as a loss in the weight of the entire population - $L$.

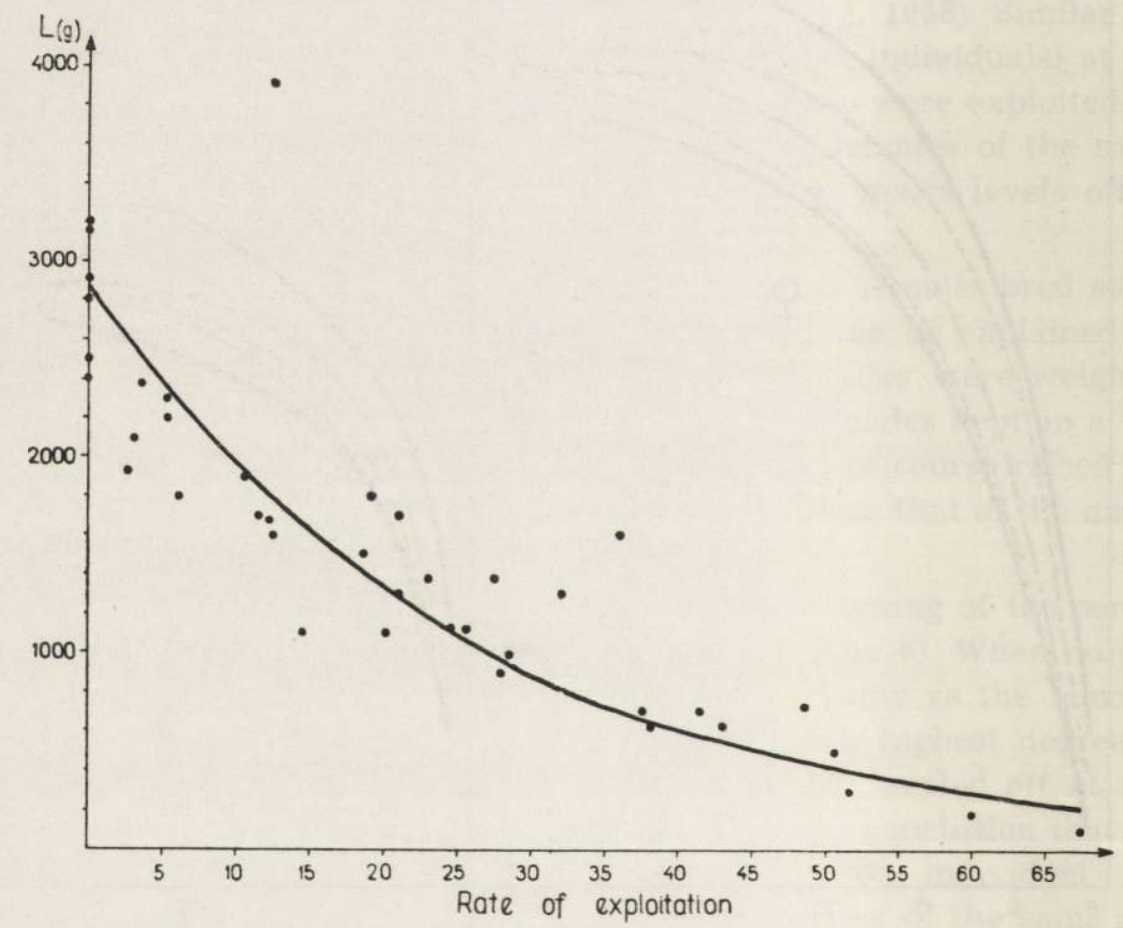

Fig. 14. Losses in the body weight of individuals (L) according to the degree of exploitation.

(1) $\mathbf{y}^{\prime}=2850.00 .963 x, \mathrm{n}=40$

The analysis has shown that the more intensive the exploitation the more the population loses weight (Fig. 14). In the non-exploited population the sum of losses in body weight in the study period amounted to $2,850 \mathrm{~g}$, while in the case of the most intensive exploitation it amounted to $220 \mathrm{~g}$. However the amount of biomass produced in the population, as well as the number of individuals, also varies according to the intensity of exploitation (Fig. 3 and 6). In the period when the amount of biomass produced declines, the value of body weight losses can also go down quite automatically. In order to have data irrespective of the variations in the 
biomass production, index $L: P$ has been analysed (it is the ratio between all the losses of body weight $(L)$ and the total production of the population $(P))$.

From the outset of the experiment until the moment when exploitation was started, the value of this index was very similar for all the populations and amounted, on the average, to 0.09 . Over the entire study period the values of index $L: P$ formed a gradient, the more mice that were removed, the smaller the losses in the body weights of the individuals which

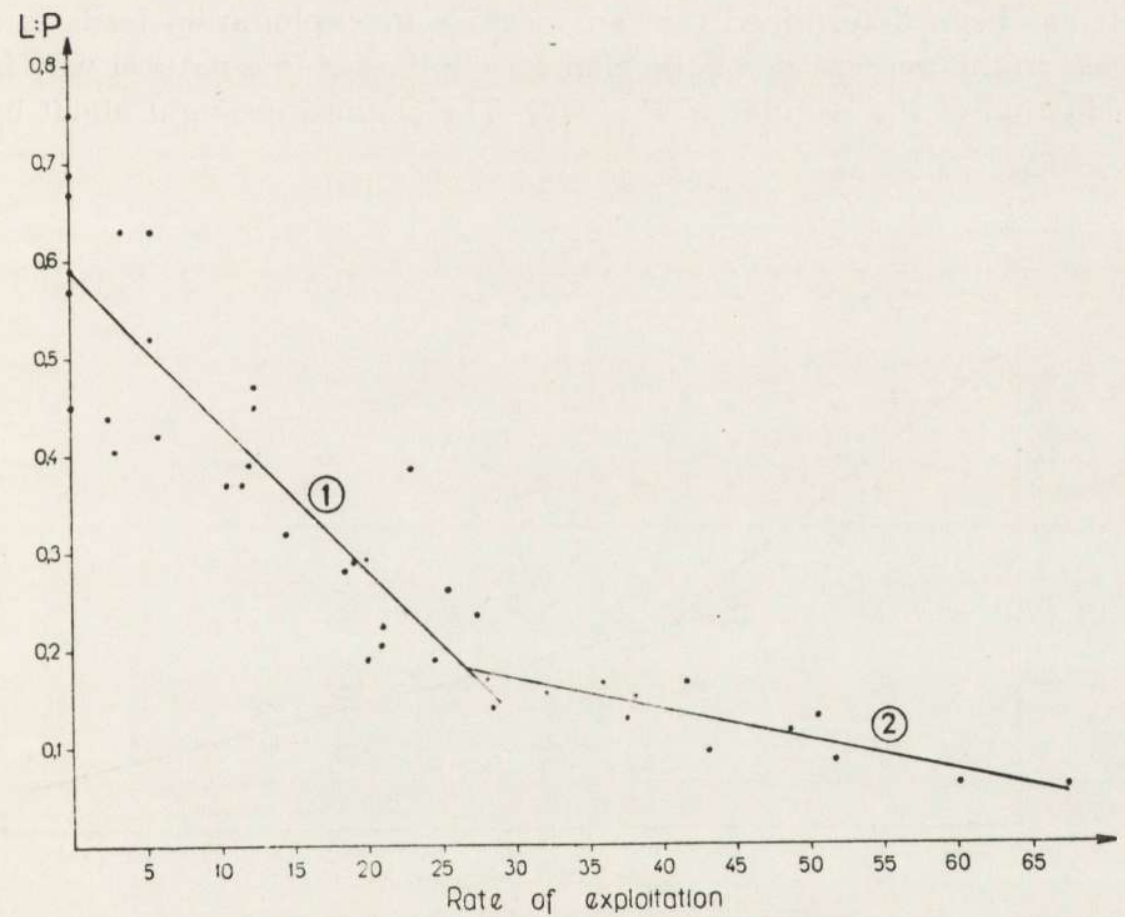

Fig. 15. Losses in the body weight of individuals recalculated per one gramme of the biomass produced $(L: P)$ in respect of exploitation.

(1) $r=-0.8834, \mathrm{n}=29, y^{\prime}=-1.5315 x+59.3915$

(2) $r=-0.8491, \mathrm{n}=14, y^{\prime}=-0.3355 x+27.4279$

were left in the population (Fig. 15). For non-exploited populations the index amounted to 0.59 , when exploitation reached $26.7 \%$ it amounted to 0.18 , and when the intensity of exploitation was at its highest it was only 0.05 .

\subsection{Self-elimination of Individuals and Biomass $(E)$}

Part of the individuals were eliminated as a result of natural mortality which depends on various ecological factors. The author analysed the de- 
pendence between the percentage of the biomass eliminated by way of natural mortality in the total population production and the degree of exploitation intensity. The sum of the body weights of all the mice which perished is the biomass eliminated in a natural way. However, mice can perish at any time between the successive daily check periods. The body weight of a dead individual decreases as the time goes by. Some individuals, particularly juveniles, are eaten up. In view of this, the last result of weighing before death was taken as the body weight of the dead mouse.

It has been determined that an increase in exploitation leads to a decrease in the percentage of the biomass eliminated in a natural way in the production of the population (Fig. 16). The changes brought about by the

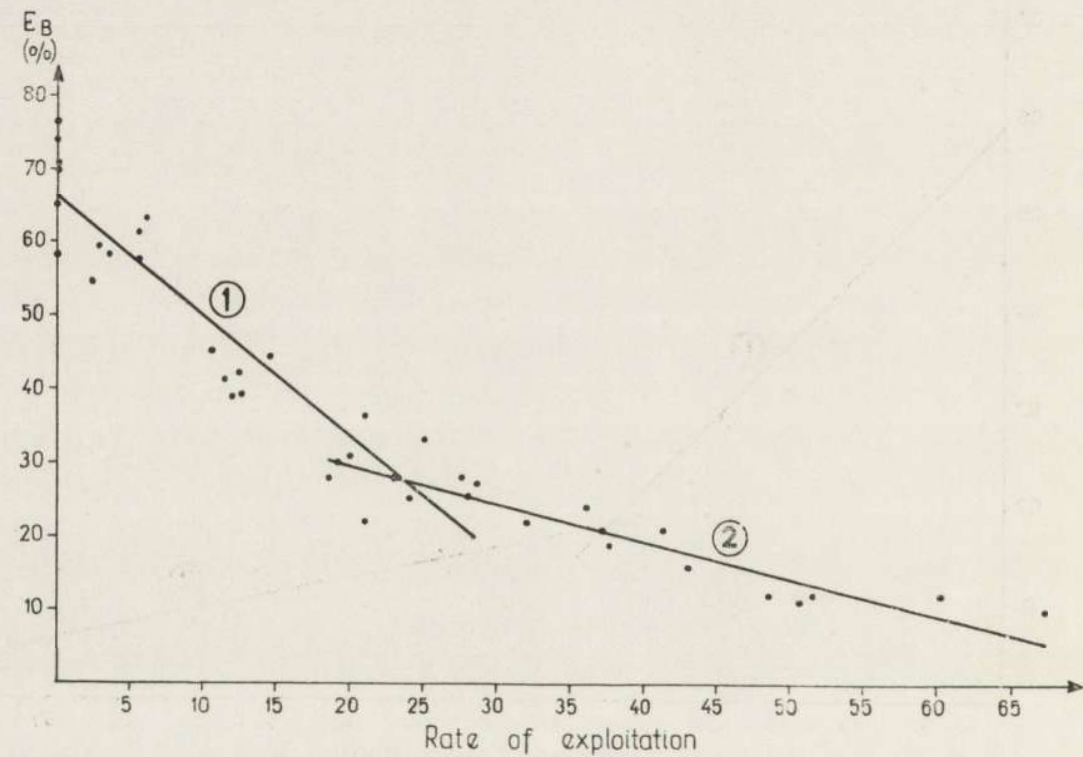

Fig. 16. Dependence of the percentage of dead individuals biomass $\left(E_{B}\right)$ in the total production $(P)$ on the degree of exploitation.

(1) $r=-0.9387, \mathrm{n}=29, y^{\prime}=-1.6052 x+65.6658$

(2) $r=-0.9037, \mathrm{n}=22, y^{\prime}=0.4933+39.6530$

intensification of exploitation are bigger in the case of exploitation between 0 and $23.4 \%$ as then elimination drops from $65.7 \%$ down to $28.1 \%$. Any further intensification of exploitation results in a somewhat slower rate of decrease in the biomass eliminated. For the most intensive exploitation this percentage amounted to $6.4 \%$. An intensification of exploitation also results in the decline in the percentage of dead individuals in the total number of mice (Table 2, line 7). In the non-exploited populations this percentage amounted to $90.3 \%$, while exploitation equal to $67.4^{\%} \%$ resulted in a decrease to $35.4 \%$. 


\section{DISCUSSION}

The numbers of individuals in a population can react in a number of ways to exploitation. For instance, $\mathrm{S} \mathrm{l} \mathrm{o} \mathrm{b} \mathrm{o} \mathrm{d} \mathrm{k} \mathrm{in} \mathrm{(1957)} \mathrm{in} \mathrm{his} \mathrm{experiment}$ with Daphnia, and Hillbricht-Ilkowska \& Pourriot (1969) with rotifers failed to record any compensation of numbers when exploitation is applied: numbers decreased when exploitation was intensified. On the other hand, after experimenting with stick insects, T a rwid (1962) came to the conclusion that average numbers were not affected by the removal of individuals. W a t t (1958) also did not record any dependence of the average numbers (standing crop) on exploitation in Tribolium, and he pointed out that the standing crop of the biomass or population numbers can not be used as an index of the population production. The same was shown in the case of rodents (P etrusewicz, 1966a; Ryszkowski \& Petrusewicz, 1967), with attention being drawn do unequal turnover occurring with different populations of the same size which may lead to different values of production.

In rodents numbers may or may not be dependent on exploitation. Most probably this is connected with the intensity and frequency of exploitation. We can imagine a low intensity exploitation applied at long intervals which leads to no numerical changes. There is a possibility of the occurrence of additional compensating mechanisms, beside those which are found in confined populations (e.g. immigration), leading to a rapid return to the previous numerical state. As an example we can quote the experiment carried out by S m y th (1968) in which he could not lower substantially the numbers of a population of Clethrionomys glareolus ( $\mathrm{S} \mathrm{ch} \mathrm{r}$ eb e r, 1780) under natural conditions because all the time new individuals immigrated into the study area. Also $\mathrm{K} \mathrm{r}$ e b s (1966) did not record any differences between the numbers of the control population of Microtus californicus ( $\mathrm{P}$ e a l e, 1848) and the exploited one as a result of intensive immigration.

In the present experiment with mice under laboratory conditions the intensity of exploitation and its frequency did not result in the compensation of numbers and biomass - they decrease when the exploitation is intensified.

Even if compensating mechanisms were not sufficient to maintain the numerical state, it was possible to record the action of the compensation of production expressed in the total number of individuals present in the population and in the biomass until the moment when the exploitation exceeded $32-34 \%$. The action of compensation mechanisms was not sufficient under the conditions of a more intensive exploitation and production clearly declined. A similar phenomenon of the compensation of 
production was observed for populations of other species. W a t t (1958) decribed an almost linear positive dependence between exploitation and the total number of newly produced Tribolium individuals and the value of the population biomass. The removal up to $99 \%$ of Lucilla imagos from a population resulted in an increased production of adults $(\mathrm{N} \mathrm{i} \mathrm{c} \mathrm{hol} \mathrm{s} \mathrm{o} \mathrm{n,}$ 1954).

These examples indicate that the destruction of a part of the population does not necessarily lead to a decline in its production. This provides ground for a more cautious estimate of the effect of the factor reducing the population, as for instance predators against a population of rodents or man attempting to control a population of rodents.

On the other hand the dependence of production on exploitation will vary in different species. The size of production yielded by a population depends on the action of compensating mechanisms. N a u mov \& $\mathrm{Ni}$ k o l s k i j (1962) divided species into two types: (1) those which are more stable and which slowly rebuild their numbers, and (2) those which are more fertile but live shorter lives and are characterized by considerable numerical oscillations. Small rodents belong to the latter category.

Figure 17 presents a pattern of the action of compensating mechanisms in exploited mouse populations. Exploitation can affect the population by altering its density and changing the organization of the population: the removal of individuals decreases automatically their numbers at least on the day of the removal and can affect the intensity of contacts and relations between individuals.

Most attention has so far been devoted to the role of reproduction and survival of individuals in the numerical regulation of a population of rodents. High reproduction in rodents adapts them to various extreme conditions under which they live. Some authors are of the opinion that reproduction is the most important compensating factor. Strecker \& $\mathrm{E} \mathrm{m}$ l e $\mathrm{n}$ (1953) recorded that the discontinuance of population growth in confined populations was due to a cessation of reproduction. On the other hand no decline in the reproduction rate was observed in unconfined populations (Strecker, 1954) as there was a possibility of migration. C r ow cr of t \& R ow e (1957) considered a decline in the reproduction of females as the main factor reducing the increase of a confined population. S o u thw i c k (1955) observed that reproductive responses to crowding varied greatly among populations; the major mechanism of population limitation was excessive litter mortality, which had been described before by B row $\mathrm{n}$ (1953), and indicated that mortality in young individuals is an important regulating factor. Petrus ew i c z (1963) observed the compensating action of natality and mortality in juvenile mice in 127 
confined mouse populations when some alien individuals were introduced or when some individuals were periodically removed from the population for a few days.

It can be inferred from the examples quoted above that both compensating mechanisms - reproduction and mortality - do not act to the same extent in each population situation, and sometimes only one of them can be recorded.

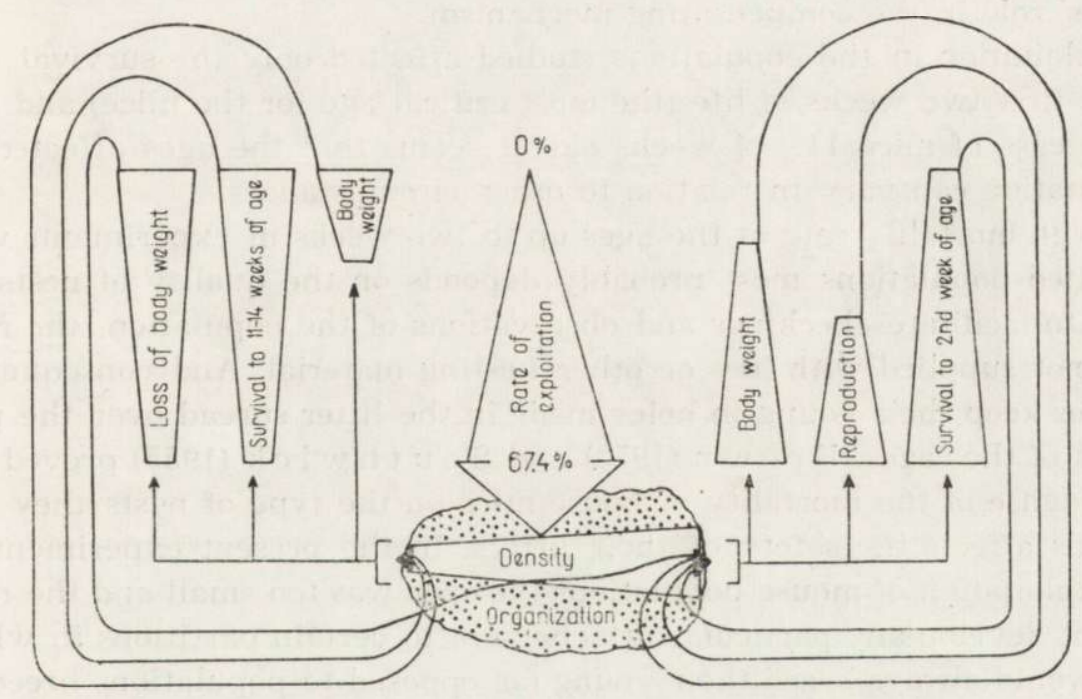

Fig. 17. Scheme of compensation mechanisms of the exploited mouse population. The fat arrow in the middle indicates the index of exploitation increasing downwards. The columns on the right-hand side - populational parameters which increase when exploitation is intensified, those on the left-hand side - decreasing parameters. The arrows indicate the direction of the action.

In the described populations of experimentally exploited mice the action of both these mechanisms was observed but their role was found to be different. The method chosen for the purposes of the present paper enables one to express reproduction by a number of indexes: (1) number of mice born per population (this was accepted as production expressed by the number of individuals); (2) number of females which reached their 11 th week of life, i.e. the age at which they have their first litter; (3) number of newborn mice per 11-week old female.

All these indexes remain unaltered until the index of exploitation exceeds $33-36 \%$. An increase in exploitation results in a decline in the total number of newborn mice and the number of females which start breeding, but at the same time there can be observed an increase in the Acta theriol. 21 
number of newborn mice per female. An increase in the number of newborn mice per female occurs when the production of a population declines so that the increase in the natality can only cushion a general decline in the production but is in no way a complete compensation.

The results of the experiment indicate that the basic compensating mechanism was an alteration in the mortality rate which decreased when exploitation was intensified. Not every age group reacted in the same way to the intensity of exploitation which indicates a differentiation of these groups' role in the compensating mechanism.

Exploitation in the populations studied affected only the survival rate in the first two weeks of life (the most critical age for the mice) and also in the case of mice 11-14 weeks old. It seems that the ages affected by exploitation can vary in relation to other circumstances.

A high mortality rate at the ages up to two weeks in experiments with exploited populations most probably depends on the quality of nests. In order to facilitate checkings and observations of the population, the mice were not supplied with hay or other nesting material. And consequently females keep their young in holes made in the litter spread over the partitions of the cages. B r ow n (1953) and S o u t h w i ck (1955) proved the dependence of the mortality of house mice on the type of nests they live in. This affects the safety of their litters. In the present experiment on the exploitation of mouse populations the cage was too small and the mice did not develop any particular attachement to certain partitions in which they would always breed their young (as opposed to populations breeding within larger and more complicated areas (P etrusewicz, 1966b). Consequently all the population disturbances affected the newborn mice as the mice could freely roam in all the nests influencing in a variety of ways on the growth and development of the young.

A decrease in the population numbers decreased the number of mice interfering with the nests and thus there was less possibility for mechanical damage and devouring the litters.

In the experiment discussed the mortality index of mice older than two weeks did not display any dependence on the degree of exploitation intensity with the exception of the period when mice are $11-14$ weeks old. At the age 11-14 weeks there occurs a reverse dependence: the more mice removed, the lower the survival rate of the remaining ones. It is not easy to explain this phenomenon. Females have their first litter usually in the eleventh week of their life and most probably we can find here some connection with the reaction of individuals belonging to this age group to the stimulus of exploitation. If this is common, then it would be an unusual process counteracting compensation. In other periods of mouse life no dependence between survival and exploitation was recorded. 
All tis indicates that only mice not older than two weeks form the reserveof populations which reacts to disturbances in production, increasing or cecreasing its size in case of "need «. That is why the survival of individuas not older than two weeks is the main compensation factor.

Wher we consider the problem of the compensation of the biomass existing in the population, then gaining weight would be compensating in its character.

Theoetically two populations characterized by a similar curve of individual srowth can differ by the amount of losses in body weight. In one populaton the increase may be due to constant addition of weight (which can be smaller or larger), while in another after periodical increases in the bod weight of separate individuals they lose weight or the other way round. The present experiment proved that the greater the exploitation the smaller the weight losses (Figs. 14 and 15). And similarly a decrease in the censity of the population provides more favourable conditions for smaller losses of body weight.

The ourse of the curve of individual growth may vary even in populatiois bred under identical conditions (W a lkowa \& Petrusew i c z, 1967). Wide differences between the average body weights of mice of the sime age were also recorded in the population described when no expbitation was applied or when there were only small differences in the intensity of exploitation.

Variations in the body weights of individuals of the same age were also recordel for other rodent species living under natural conditions. There were atempts to determine certain factors affecting the body weights. Among others, Wi jngaarden (1960) and Bujalska \& Gliwicz (1968) fund out that body weight depends on the season, while $\mathrm{H}$ e a le $\mathrm{y}$ (1967) asserted that it depends on aggressiveness of the males.

Expleitation is a factor affecting also the growth of individuals older than 5 veeks, but the reaction to this effect can assume varying characters. A low degree of exploitation intensity (up to $15 \%$ ) lowers the curve of grouth, while any intensification of exploitation clearly increases the body weights. The increase in the body weight of individuals which occurs when exploitation exceeds $15 \%$, is most probably caused by a decline in the density which is the result of removing the mice.

A sinilar phenomenon was observed in the case of some fish species ( $\mathrm{N} \mathrm{i} \mathrm{k} \mathrm{ol} \mathrm{s} \mathrm{k} \mathrm{i} \mathrm{j,} \mathrm{1965).} \mathrm{It} \mathrm{has} \mathrm{already} \mathrm{been} \mathrm{mentioned} \mathrm{here} \mathrm{that} \mathrm{the} \mathrm{aggres-}$ sivenesı of males leads to a decrease in the body weight of adult Peromyscus individuals ( $\mathrm{Healey}, 1967)$. If the same occurs in mice, we could expect a dependence of the curve of individuals growth on the density, as aggressiveness increases when the density is higher ( $\mathrm{S}$ o $\mathrm{ut} \mathrm{h}$ - 
wi ck, 1955). Under conditions of low density there can be larger increases in the body weight of individuals.

A similar argument can not be put forward in the case of a low intensity exploitation when a decrease in density leads to a decrease in the body weight. Here the body weight must be affected by a factor other than density. The only explanation can be the acceptance of the hypothesis that the population structure is destroyed in this case. Disturbances in the structure caused by the removal of individuals can at high densities and small numerical decreases play a more important role in the population than changes in the density itself. Hence the tendency to smaller body weight gains and the lower course of the curve of individual growth. However, in the case of sharp density drops, the effect of low numbers is more evident than disturbances caused by exploitation. As a result of this a high intensity exploitation causes a rapid increase in the body weights and the course of the curve of individual growth is then quite high.

The character of the dependence between the curve of individual growth and the degree of exploitation intensity described above indicates that the exploitation of individuals is a stimulus whose two aspects can be distinguished: (1) it decreases the population numbers (density), and (2) it disturbs in a certain way the organization of the population.

The experiments of P e t r u s e w i c z (1963) proved the existence of the latter stimulus. The removal of a few males or females for a short period of time (so that no permanent changes in the population numbers are brought about) led in most cases to an increase in numbers as compared with the control populations. This phenomenon was observed even in cases when the population numbers were on the decrease. This indicates that the removal itself without any numerical changes is a strong stimulus for the population. Summing up, it can be said that the body weights of individuals become a compensating factor only in the case of exploitation exceeding $15 \%$.

The pattern according to which the compensating mechanisms operate described above (Fig. 17) reveals that various compensating factors do not act simultaneously when the intensity of only one stimulus varies (exploitation).

\section{CONCLUSIONS}

1. Exploitation (removal of individuals) of mouse populations under laboratory conditions leads to the occurrence of compensating mechanisms.

The combination of these mechanisms analysed for the purposes of the present paper is not sufficient to compensate the population numbers when the intensity of exploitation changes. The average numbers and 
biomass of the population decrease when the exploitation is intensified (Table 2, lines 1 and 2). The numerical peak is also then decreased (Table 2 , line 3$)$.

2. The action of compensating mechanisms results in a compensation of production expressed by the total number of mice in the population $(v)$ or the biomass produced $(P)$ in the case when the intensity of exploitation does not exceed $32-34 \%$. Any further intensification of exploitation causes a decline in production (Figs. 3 and 6).

3. Natural elimination expressed by the number of dead individuals and the biomass of dead mice in the population declines when the exploitation is intensified (Fig. 16, Table 2, line 7), i.e. mortality (or conversely survival) occurs as a compensating factor.

4. The survival of individuals not older than two weeks is the most important compensating factor as it acts within the entire range of the exploitation gradient and it varies considerably (Fig. 12): from $21 \%$ when no exploitation was applied to $66 \%$ in the case of the most intensive exploitation. The survival rate of juvenile mice most probably depends on the exploitation of adult mice.

The survival of mice at the age of $11-14$ weeks displays a reverse tendency: it decreases when the exploitation is intensified. The size of these changes, however, is not very significant (Fig. 11).

In other age groups no dependence of survival on exploitation was recorded (Table 4).

5. The number of breeding females and the number of newborn mice per female do not depend on exploitation within the range of $0-36 \%$ (Figs. 7 and 8), i.e. within this range there can be a compensation of production. When exploitation is intensified the number of newborn mice per female is increased but not enough to counteract sufficiently the decline in production as simultaneously the number of breeding females declines as well.

6. Changes in the body weights of mice occur as a compensating factor in individuals older than 5 weeks and when the exploitation exceeds $15 \%$. A lower degree of exploitation intensity leads to a decrease in the body weights as compared with individuals of the same age in non-exploited populations (Fig. 13).

Young males grow more quickly than the females. The average body weight of an adult female is higher than the body weight of males of the same age (due to the fact that pregnant females are also taken into account). The age at which males and females have the same body weight shortens from 11 to 7 weeks when the exploitation is intensified which may suggest that mice develop faster in exploited populations (Table 2, line 6). 
Losses of body weight decrease when the exploitation is intensified (Figs. 14 and 15).

7. Exploitation leads to a change in the structure of the biomass produced. In the population production, when the exploitation is intensified (Fig. 5): (a) the percentage of the biomass production of newborn mice declines, (b) the percentage of the biomass production of individuals not older than 5 weeks increases, (c) the percentage of the biomass production of females (not taking into account their litters) declines, (d) the percentage of the production of individuals not older than 2 weeks does not change, (e) the male percentage of the biomass produced does not change either.

The biomass production changes in the period of the population development: the widest differentiation of production in time was observed when exploitation was in the range $0-15 \%$, while the most stable production was in the range $15-30 \%$ (Fig. 4).

Acknowledgements: I wish to express my sincere thanks to Professor Dr. K. P e$\operatorname{trusewicz}$ for his generous help and advice during the studies, Dr. Z. Pucek, Dr. P. Trojan and Dr. L. Ryszkowski for critical examination of this manuscript and to J. G 1 og ow s k a, M. Sc. for her help in statistical analyses of data. My thanks are also due to Dr. Ch. North for correction of the English text.

\section{REFERENCES}

1. Adamczyk K. \& Petrusewicz K., 1966: Dynamies and intrapopulation differentiation of a free-living population of house mouse. Ekol. pol., A, 14, 36: $725-740$.

2. Brody S.: 1945: Bioenergetics and growth. Reinhold: 1-1023. New Jork.

3. Brown R. Z., 1953: Social behaviour, reproduction and population changes in the house mouse (Mus musculus L.). Ecol. Monogr., 23: 217-240.

4. Bujalska G. \& Gliwicz J., 1968: Productivity investigation of an island population of Clethrionomys glareolus ( $\mathrm{S} \mathrm{ch} \mathrm{r}$ e be r, 1780). III. Individual growth curve. Acta theriol., 13, 25: 427-433.

5. Crowcroft P. \& R owe F. P., 1957: The growth of confined colonies of the wild house mouse (Mus musculus L.). Proc. zool. Soc. Lond., 129: 359-370.

6. Davis D. E., Christian J. J. \& Bronson F., 1964: Effect of exploatation on birth, mortality, and movement rates in a woodchuck population. J. Wildl. Mgmt, 28, 1: 1-9.

7. Fisz M., 1958: Rachunek prawdopodobieństwa i statystyka matematyczna. Państw. Wyd. Nauk.: Warszawa.

8. Gołoduško B. Z. \& Fomenkov A. H., 1969: Nekotoryje itogi ispolzowanija zapasov bobra w Belorussii. Meždunarodnyj Kongress biologov-ohotovedov. Moskva.

9. Grünberg H., 1952: The genetics of the mouse. Martinus Nijhof: $1-650$, Hague.

10. H e a l e y M. C., 1967: Aggression and self-regulation of population size in deermice. Ecology, 48: $377-392$. 
11. Hillbricht-Ilkowska A. \& Pourriot R., 1969: Produkcja eksperymentalnych populacji Brachionus calyciflorus ( $\mathrm{Pallas}$ ) poddanych sztucznemu drapieżnictwu o różnej intensywności. Pol. Arch. Hydrobiol. 17 (in print).

12. Ketchum B., Lillick J. \& Redfield A. C., 1949: The growth and optimum yields of unicellular algae in mass culture. J. cell. comp. Physiol. 33: 267 -279 .

13. Krebs C. J., 1966: Demographic changes in fluctuating populations of Microtus californicus. Ecol. Monogr., 36: 239-273.

14. Kovalevskij K. L., 1958: Laboratornoe životnovodstvo. Medgiz: 1-324, Moskva.

15. M a y nard L. A. \& Loosli J. K., 1967: Naukowe podstawy żywienia zwierząt. Państw. Wyd. Roln. i Leśn.: 1-572, Warszawa.

16. Myrcha A. \& W a lkow a W., 1968: Changes in the caloric value of the body during the postnatal development of white mice. Acta theriol., 13, 22: $391-400$.

17. Naumov N. P. \& Nikolskij G. V., 1962: O nekotoryh obščih zakonomernostjah dinamiki populacij životnyh. Zool. ž., 41, 8: 1132-1141.

18. Nichols on A. J., 1954: An outline of the dynamics of animal populations, Aust. J. Zool., 2, 1: 9-65.

19. Nikolskij G. V., 1965: Teorija dinamiki stada ryb. Nauka. Moskva.

20. Petrusewicz K., 1957: Investigation of experimentally induced population growth. Ekol. pol. A, 5, 9: 282-309.

21. Petrusewicz K., 1960: Some regularities in male and female numerical dynamic in mice populations. Acta theriol., 4, 8: 103-137.

22. Petrusewicz K., 1963: Population growth induced by disturbance in the ecological structure of the population. Ekol. pol. A, 11, 3: 87-125.

23. Petrusewicz K., 1966: Niektóre pojęcia w badaniach produktywności wtórnej. Kosmos, 2: 581-599.

24. Petrus ew ic z K., 1966a: Production vs. turnover of biomass and individuals. Bull. Pol. Acad. Sci., Cl. II, 14, 9: 621-625.

25. Petrusewicz K., 1966b: Dynamics, organization and ecological structure of population. Ekol. pol. A, 14, 25: 413-436.

26. Petrusewicz K., 1967: Concepts in studies on the secondary productivity of terrestrial ecosystems. [In "Secondary productivity of terrestrial ecosystems ", Ed. K. Petrusewicz], 1: 17-49. Polish Sci. Publ., Warszawa-Kraków.

27. Petrusewicz K. \& Andrzejewski R., 1962: Natural history of a free-living population of house mice (Mus musculus L.) with particular reference to groupings within the population. Ekol. pol. A, 10, 5: 85-122.

28. Petrusewicz K., Andrzejewski R., Bujalska G. \& Gliwicz J., 1968: Productivity investigation of an island population of Clethrionomys glareolus ( $\mathrm{S} \mathrm{chre} \mathrm{ber,} \mathrm{1780).} \mathrm{IV.} \mathrm{Production.} \mathrm{Acta} \mathrm{theriol.,} \mathrm{13,} \mathrm{26:} \mathrm{435-445.}$

29. Petrusewicz K. \& W a lkowa W., 1968: Contribution of production due to reproduction to the total production of the population and individuum. Bull. Pol. Acad. Sci., Cl. II, 16, 7: 439-442.

30. Ryszkowski L. \& Petrusewicz K., 1967: Estimation of energy flow through small rodent populations. [In »Secondary productivity of terrestrial ecosystems«, Ed. K. Petrusewicz], 1: 125-146. Polish Sci. Publ., Warszawa-Kraków. 
31. Slobodkin L. B., 1957: A laboratory study of the effect of removal of newborn animals from a population. Proc. natn. Acad. Sci. USA, 43, 8: 780-782.

32. Slobodkin L. B., 1962: Predation and efficiency in laboratory populations. [In: "The Exploitation of Natural Animal Populations«. Eds. E. D. Le Cren \& M. W. H o ld g a t e]: 223-241. Blackwell Sci. Publ., Oxford.

33. S m y th M., 1968: The effects of the removal of individuals from a population of bank voles Clethrionomys glareolus. J. Anim. Ecol. 37: 167-183.

34. Southwick C. H., 1955: Regulatory mechanisms of house mouse populations: social behaviour affecting litter survival. Ecology, 36: 627-634.

35. Southwick C. H., 1955a: The population dynamics of confined house mice supplied with unlimited food. Ecology, 36: 212-225.

36. Southwick C. H., 1958: Population characteristics of house mouse living in English corn ricks: density relationships. Proc. zool. Soc. London, 131: 163-175.

37. Strecker R. L. \& Emlen J. T. Jr., 1953: Regulatory mechanisms in house mouse populations: the effect of limited food supply on a confined population. Ecology, 34: 375-385.

38. Strecker R. L., 1954: Regulatory mechanisms in house-mouse populations: the effect of limited food supply on an unconfined population. Ecology, 35, 2: $249-253$.

39. Shmalhauzen I. I., 1935: Opredelenie osnovnyh ponjatij i metodika issledovanija rosta. [Sb. "Rost životnyh«. Ka pla n skij S. Ja. et al., Eds.]: 8-60. Moskva-Leningrad.

40. Tarwid K., 1962: Kompensacija samoregulaemoj biocenotičeskoj sistemy dejstvija hiščnikov. Vop. Ekol. Biotsen., 8: 119.

41. Thomps on D'Arcy W., 1961: On growth and form. Univ. Press: $1-346+\mathrm{XIV}$, Cambridge.

42. Varley G. C. \& Gradwell G. R., 1962: The interpretation of insect population changes. Proc. 15th Ann. Sess. Ceylon Ass. Adv. Sci.: 142-156.

43. W a lkowa W. \& Petruse wicz K., 1967: Net production of confined mouse populations. [In »Secondary productivity of terrestrial ecosystems«, Ed. K. P etrusewicz]. 1: 335-347. Polish Sci. Publ., Warszawa-Kraków.

44. W a t t K. E. F., 1958: Studies on population productivity. I. Three approaches to the optimum yield problem in populations of Tribolium confusum. Gen. Syst., 3: 122-147. Michigan.

45. W i jng a a rden A. V., 1960: The population dynamics of four confined populations of the continental vole Microtus arvalis (P a ll a s). RIVON Mededeling, 84: $1-28$.

Accepted, August 2, 1971.

Institute of Ecology,

Polish Academy of Science,

Dziekanów n. Warsaw. 
Wiera WALKOWA

\section{WPEYW EKSPLOATACJI NA PRODUKTYWNOŚC POPULACJI MYSZY}

\section{LABORATORYJNYCH}

\section{Streszczenie}

Doświadczenia objęły 40 populacji myszy laboratoryjnych, hodowanych przez 70 tygodni. Co 12 tygodni usuwano stały procent osobników z populacji obliczany od liczebności w dniu wyjmowania. Za wskaźnik eksploatacji przyjęto procent wszystkich usuniętych myszy od całkowitej liczby osobników populacji w badanym 70 tygodniowym okresie.

Eksploatacja (usuwanie osobników) populacji myszy w warunkach laboratoryjnych powoduje wystąpienie działania mechanizmów kompensacyjnych.

Zbadany układ tych mechanizmów nie jest wystarczający dla skompensowania liczebności populacji w warunkach różnego nasilenia eksploatacji. Srednia liczebność populacji oraz średni stan biomasy zmniejsza się wraz ze zwiększeniem stopnia eksploatacji (Tabela 2, wiersz 1,2). Zmniejsza się również wielkość szczytu liczebności (Tabela 2, wiersz 3).

Działanie mechanizmów kompensacyjnych powoduje kompensację produkcji wyrażoną ogólną liczbą myszy obecnych $\mathrm{w}$ populacji $(v)$ lub wyprodukowaną biomasą $(P)$ w przypadku gdy intensywność eksploatacji nie przekraczała $32-34 \%$. Dalsze nasilenie eksploatacji powodowało spadek produkcji (Ryc. 3, 6).

Eliminacja naturalna wyrażona liczbą osobników oraz biomasą myszy populacji spada wraz ze zwiększeniem nasilenia eksploatacji (Rys. 16, Tabela 2, wiersz 7) czyli śmiertelność (lub odwrotnie: przeżywalność) występuje jako czynnik kompensacyjny.

Przeżywalność osobników do wieku 2-ch tygodni była najważniejszym czynnikiem kompensacyjnym, ponieważ działała w całej rozpiętości gradientu eksploatacji i zakres jej zmian był bardzo duży (Rys. 12): od 21\% w warunkach braku eksploatacji do $66 \%$ przy maksymalnej eksploatacji. Przeżywalność młodych zależy prawdopodobnie od eksploatacji dorosłych.

Przeżywalność w wieku 11-14 tygodni przebiega w odwrotnym kierunku: zmniejsza się ona wraz ze wzrostem eksploatacji. Wielkość tych zmian nie jest jednak znaczna (Rys. 11).

U innych grup wiekowych nie stwierdzono zależności przeżywalności od eksploatacji (Tabela 4).

Liczba samic zdolnych do rozrodu oraz liczba noworodków przypadająca na jedną samicę nie jest zależna od eksploatacji na poziomie od 0 do około $36 \%$ (Ryc. 7 , 8), czyli w tym zakresie eksploatacji istnieje kompensacja produkcji. Wzrost eksploatacji zwiększa liczbę noworodków na jedną samicę, lecz nie na tyle aby zapobiec spadkowi produkcji, ponieważ jednocześnie następuje zmniejszenie liczby samic zdolnych do rozrodu.

Zmiany ciężaru ciała myszy występują w charakterze czynnika kompensacyjnego u osobników starszych niż 5 tygodni i w warunkach eksploatacji przewyższającej $15 \%$. Niższa eksploatacja powoduje zmniejszenie ciężaru ciała w porównaniu z osobnikami w tym samym wieku z populacji nie eksploatowanych (Ryc. 13). 
Młode samce rosną szybciej niż samice. U osobników starszych średni ciężar samicy dorosłej jest wyższy (na skutek uwzględnienia samic ciężarnych) niż ciężar samca w tym samym wieku. Wiek, w którym samce i samice mają jednakowy (czasowo) ciężar ciała, zmniejsza się z 11 do 7 tygodni wraz ze wzrostem eksploatacji, co może sugerować szybszy rozwój myszy w populacjach eksploatowanych (Tabela 2, wiersz 6).

Straty ciężaru ciała myszy (chudnięcie) zmniejszają się w miarę wzrostu eksploatacji (Ryc. 14, 15).

Eksploatacja wpływa na zmianę struktury produkowanej biomasy. Wraz ze wzrostem nasilenia eksploatacji (Ryc. 5): (a) zmniejsza się udział produkcji biomasy noworodków w ogólnej produkcji populacji, (b) zwiększa się udział produkcji biomasy osobników w wieku do 5 tygodni, (c) zmniejsza się udział produkcji biomasy samic (bez uwzględnienia rozrodu), (d) nie stwierdzono zmian w udziale produkcji osobników w wieku do 2-ch tygodni oraz udziału produkcji biomasy samców.

Produkcja biomasy nie jest jednakowa w okresie rozwoju populacji: najwyższe zróżnicowanie produkcji w czasie, zaobserwowano w przedziale eksploatacji od 0 do $15 \%$, a najbardziej wyrównaną produkcję - w zakresie równym $15-30 \%$ (Ryc. 4). 